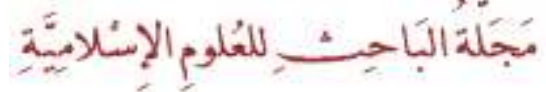

Researcher Journal For Islamic Sciences

Published by the College of Islamic Sciences at the University of Fallujah

ISSN p.p:2708-3993 / ISSN o.l: 2708-4000

Vol;1- Issue;1/ (2020-2021)

\section{Abu Hilal Al-Rasbi's Defective Narrations in Al-Daraqutni's Elal Book - A Critical Study-}

Asst. Prof. Dr. Sarmad Fouad Shafiq/ University of Fallujah - College of Islamic Sciences/dr.sarmad.alobidi@uofallujah.edu.iq / 07806006970

Abstract: After research and extrapolation, I found that there are hadiths narrated by Abu Hilal Al-Rasbi in which there are defects and I wanted to collect and study these hadiths in this research and study them in a critical study in which I explain the places of the defect, whether in the chain of transmission or in the text. - Critical study -) "Marfu' and Mawqoof" Hadiths and so on. The differences were explained graduated and studied through the sayings of scholars (may God Almighty have mercy on them). The most correct statement was shown through strong clues indicating for that. The research was divided into an introduction and three topics. Then came the conclusion, the list of sources and references.

Keywords:(Hadiths,Al-RasbiAl-Mu'ah, IllalAl-Daraqutni) 


\section{أحاديث أبي هلال الراسبي المُعلّة في علل الدار قطني}

\section{(دراسة نقدية)}

الأُستاذ المساعد الدكتور سرمد فؤاد شفيق العبيدي / جامعة الفلوجة/ كلية العلوم الاسلامية / dr.sarmad.alobidi@uofallujah.edu.iq / 07806006970

بعد البحث والاستقراء وجدت بان هناك أحاديث يرويها ابو هلال الراسبي مُعلّة ، فأردت أن أجمع هذه الاحاديث الماديث في هذا

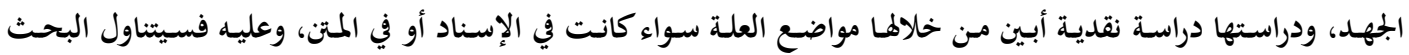

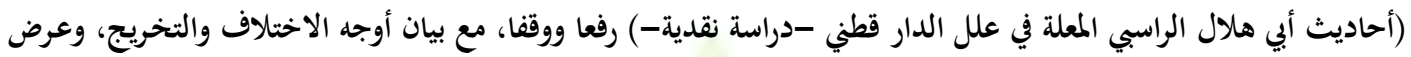

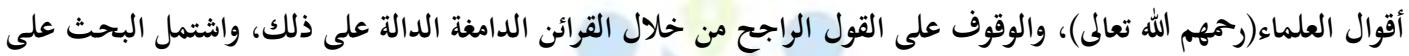

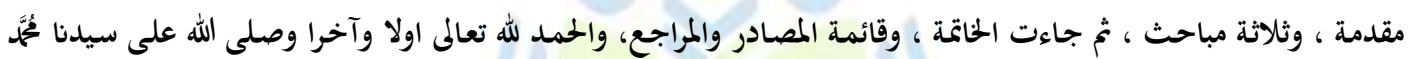

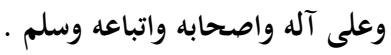
الكلمات المفتاحية: (أحاديث، الراسبي المُعلةّ، علل الدار قطني). 


\section{أحاديث أبي هلال الراسبي المُعلّة في علل الدار قطني}

\section{(دراسة نقدية)}

\section{الأُستاذ المساعد الدكتور سرمد فؤاد شفيق العبيدي \\ جامعة الفلوجة/ كلية العلوم الاسلامية}

المقدمة

الحمد لله الذي علّم بالقلم، علّم الإنسان ما لمُ يعلم، وأُصلي وأُسلم على الهادي للأُمْم سيدنا مُجمَّم وعلى آله

$$
\text { وصحبه وسلم. }
$$

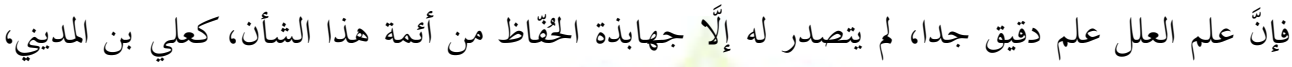

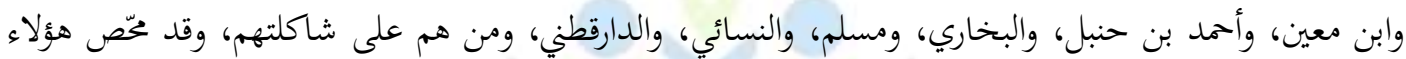

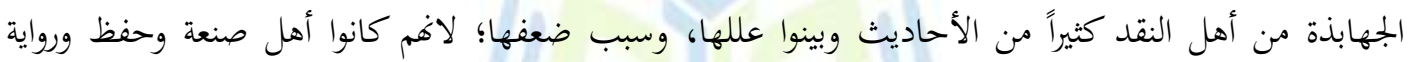

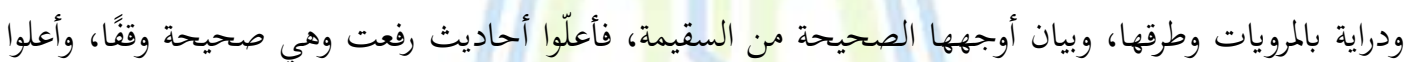

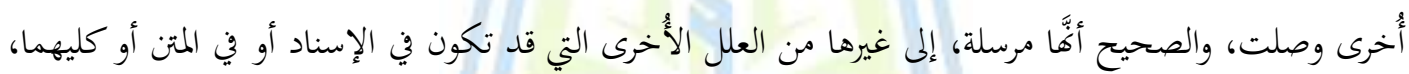

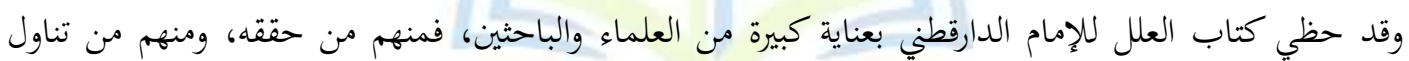

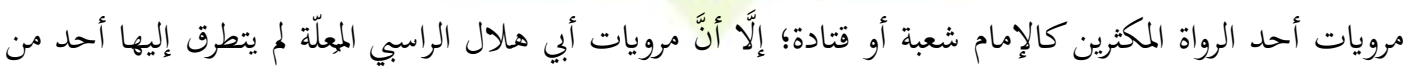

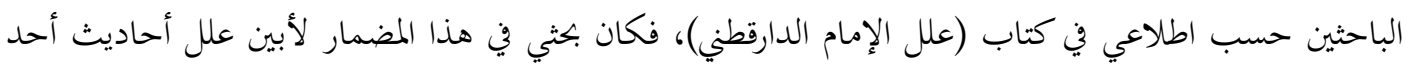

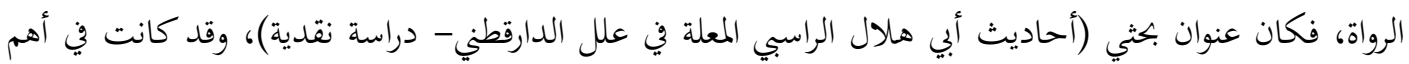

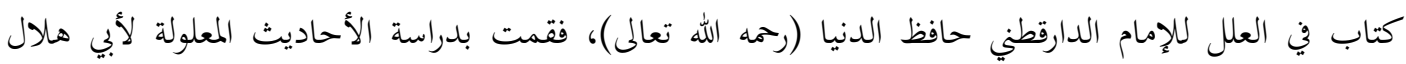

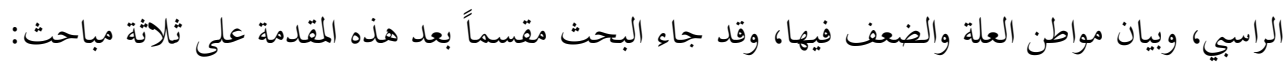

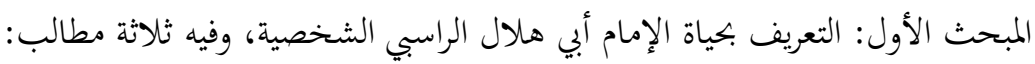

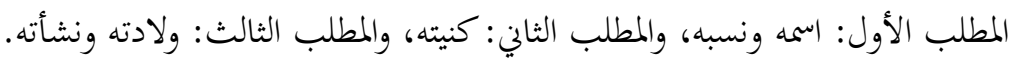

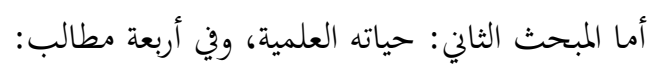
المطلب الأول: شيوخه، المطلب الثاني: تلاميذه، والمطلب الثالث: أقوال العلماء فيه، والمطلب الرابع: وفاته. 
وأما المبحث الثالث: الأحاديث المعلّة في مرويات أبي هلال الراسبي رمه الله، وفيه سبعة مطالب:

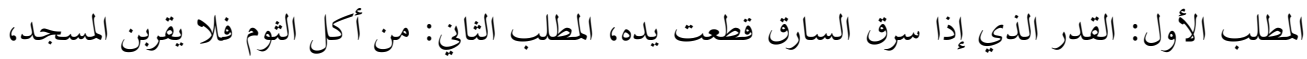

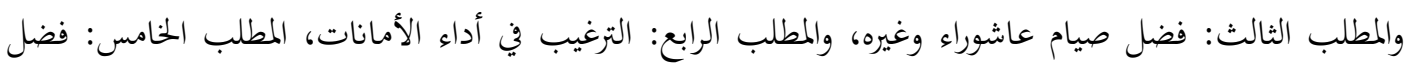

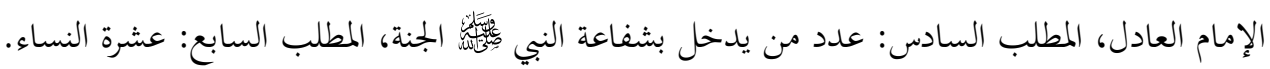

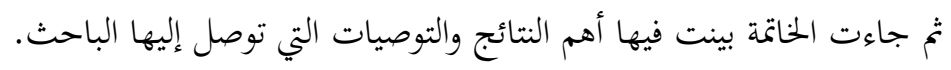

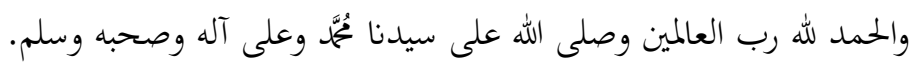




$$
\text { المطلب الأول: اسمه وناثة مطالب: }
$$

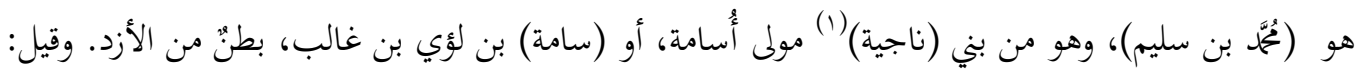

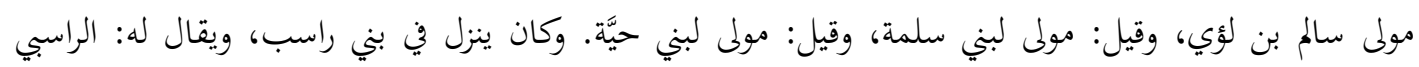

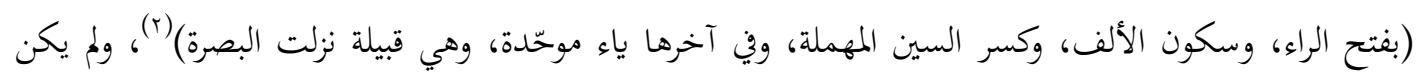

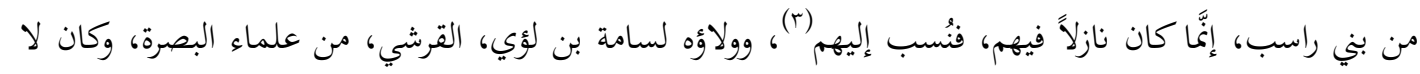

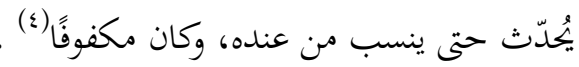

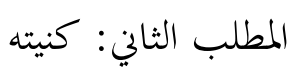

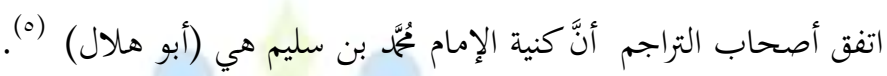

$$
\text { المطلب الثالث: ولادته ونشأته }
$$

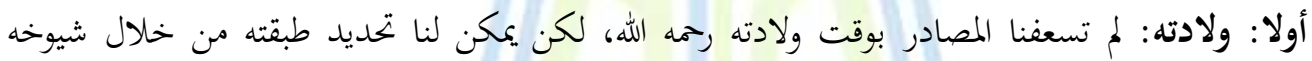

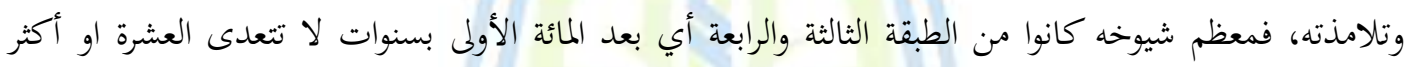

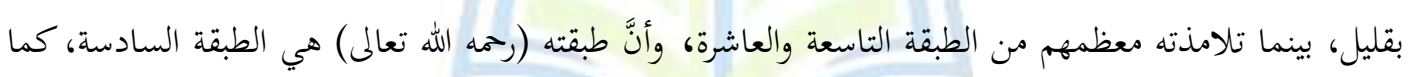
ذكر ذلك الإمام ابن حجر رمها الله تعالى (i).

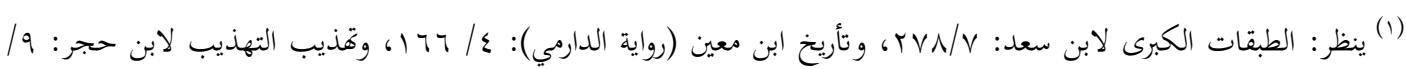
. 279

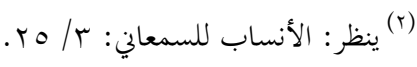

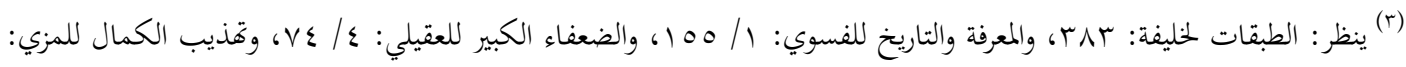

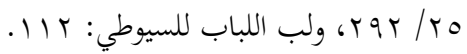

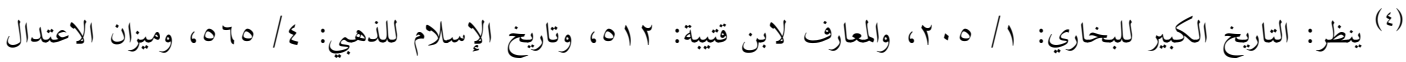

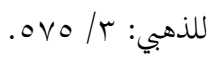

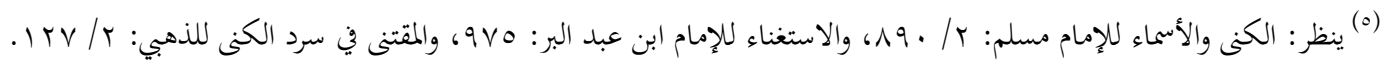
$|v|$

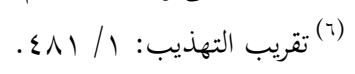


ثانياً: نشأته: لم تتكلم المصادر المعنية عن نشأته رحمه الله، كذلك لم تمتناول الكلام عن حياة والديه وأُسرته،

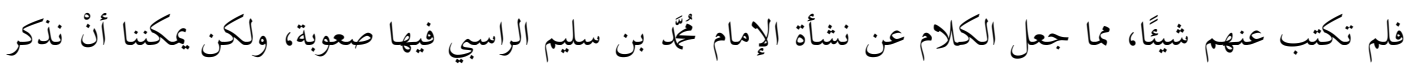

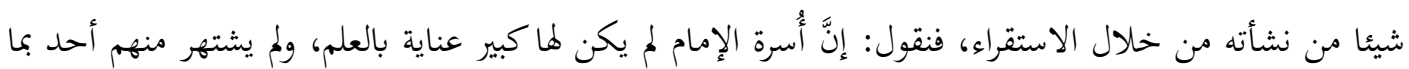

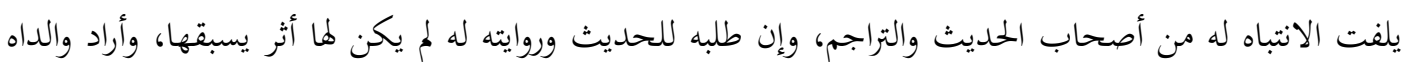

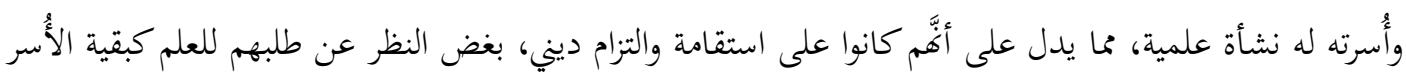

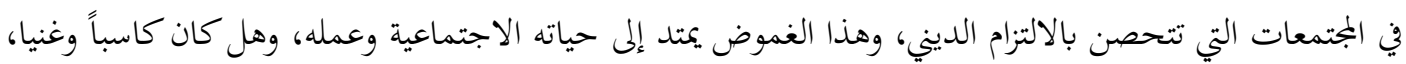

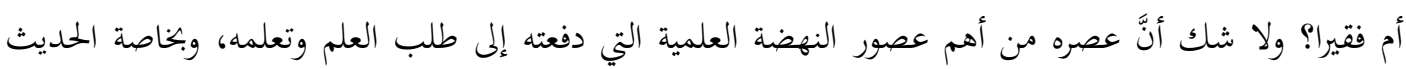

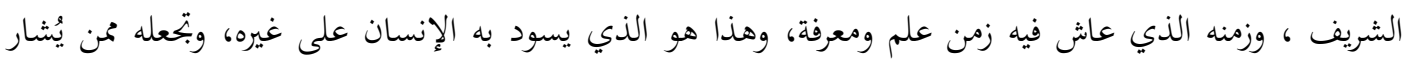

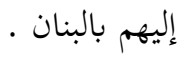

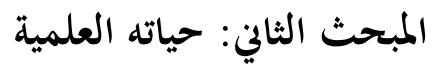

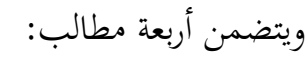
المطلب الأول: شيوخه أخذ الإمام يُمَّم بن سليم الراسبي (رحمه الله تعالى) عن كبار التابعين من أئمة الحديث، والفقه، وهم وفق

بكر بن عبدالله المزني، وتوبة العنبري البصري، وحميد بن هلال العدوي، وسوادة بن حنظلة القشيري

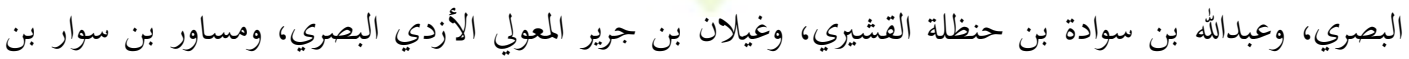

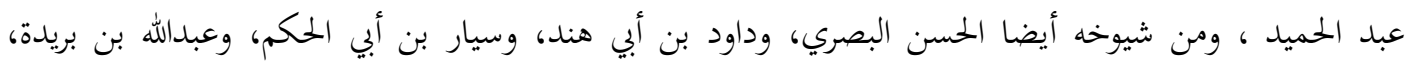

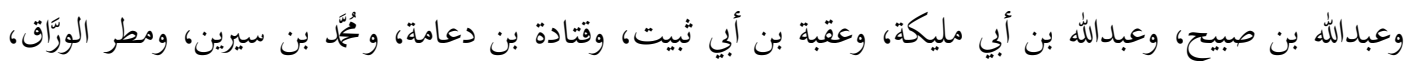
وأبي الزبير المكي، وأبي يزيد المدني، وغيرهم (1).

IVT

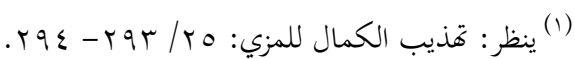




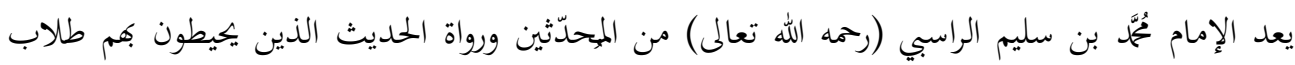

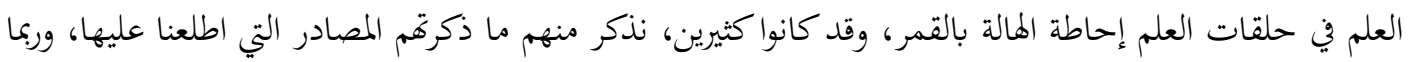
هناك كثير من التلاميذ الذين لم تذكرهم المصادر او تشير اليهم، وهم على النحو الآتي:

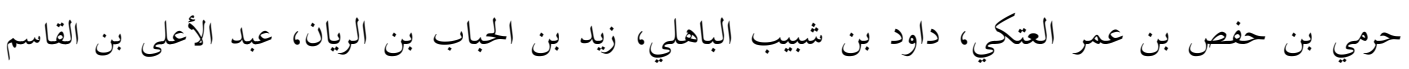

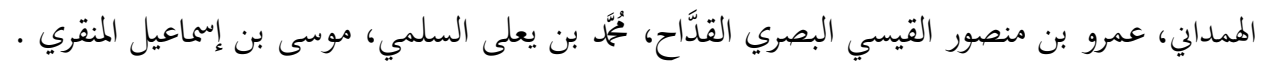

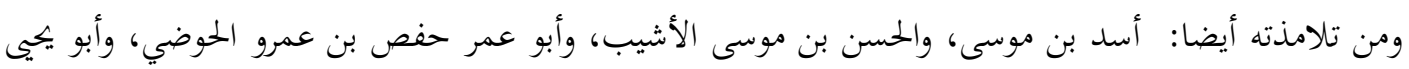

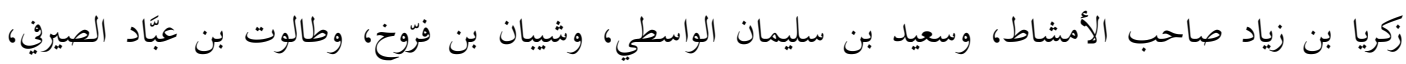

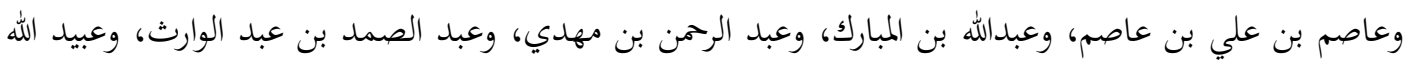

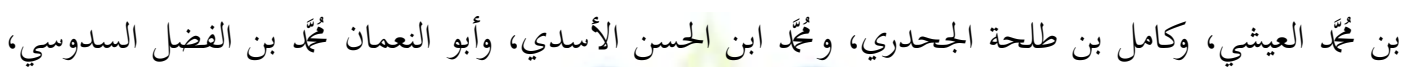

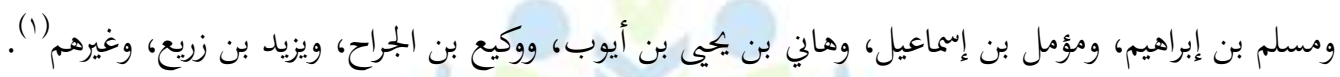

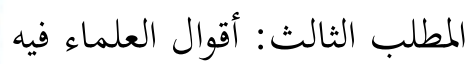

اختلفت أقوال العلماء رحمهم الله تعلى في مُحَّمَ بن سليم الراسبي (رحمه الله تعالى): فقال الإمام ابن سعد:

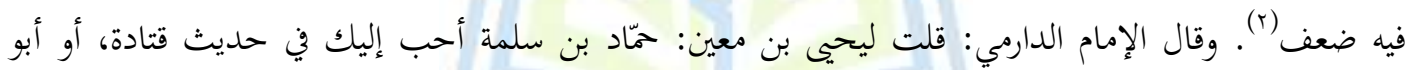

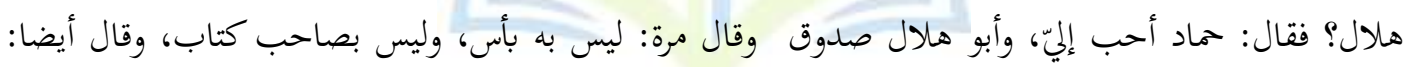

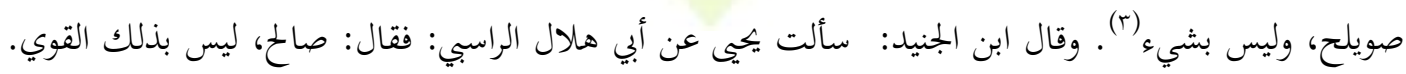

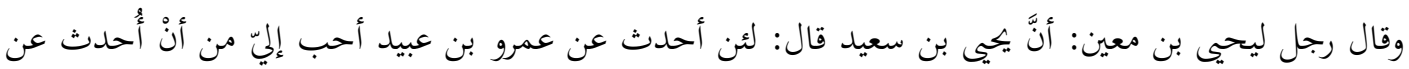

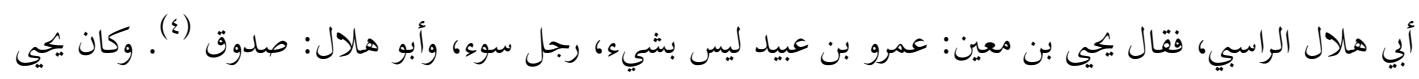

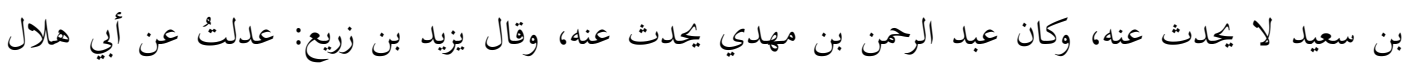

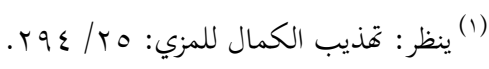

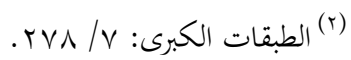

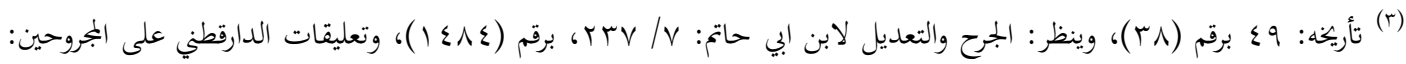

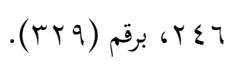

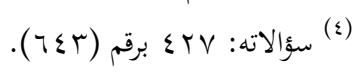

ivr 
عمدًا(). وقال أبو زرعة الرازي: ليّن وليس بالقوي(r) وقال النسائي: ليس بالقوي(r)، وقال أبو عبيد الآجري:

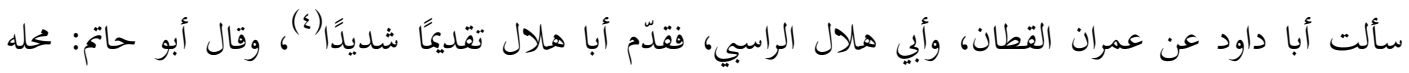

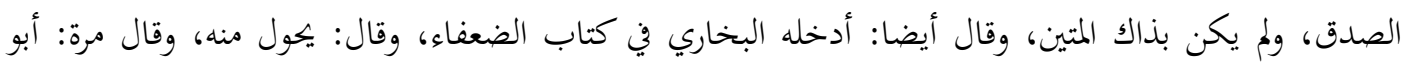

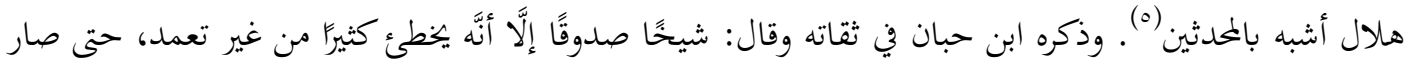

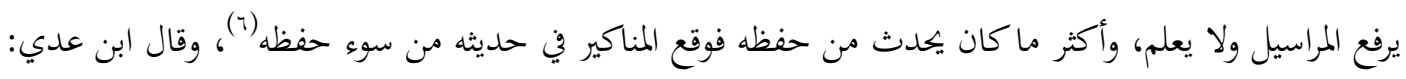

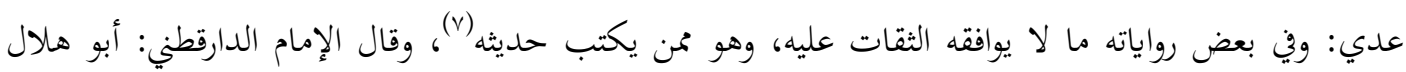

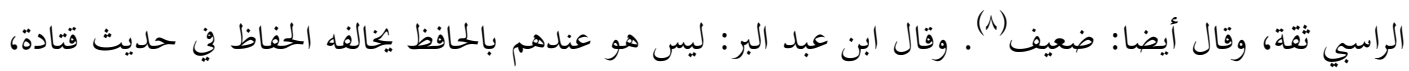

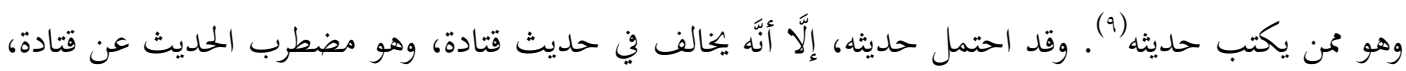
وفيه ضعف (1.)

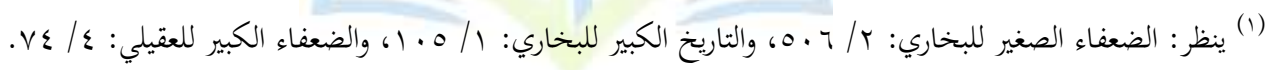

$$
\begin{aligned}
& \text { (r) }
\end{aligned}
$$

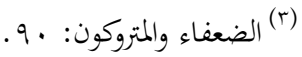

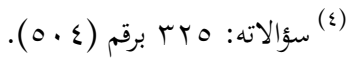

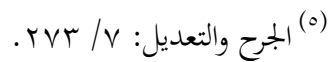

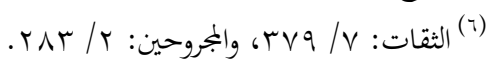

$$
\begin{aligned}
& \text {. الكامل: الك الك }(v)
\end{aligned}
$$

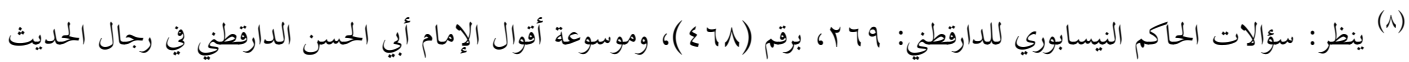

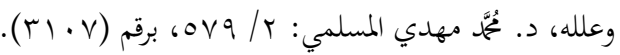

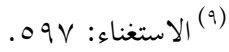

(·) ينظر: التعديل والتجريح للباجي: r/ r r ب، وموسوعة أقوال الإمام أحمد بن حنبل في رجال الحديث وعلله، أبو المعاطي النوري:

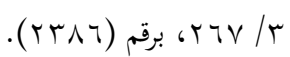

IV 
وذكره ابن الجوزي في ضعفائه(1)، وقال الذهبي: احتج بعضهم به، وهو صالح الحديث(r)، وقال البزار: احتمل الناس

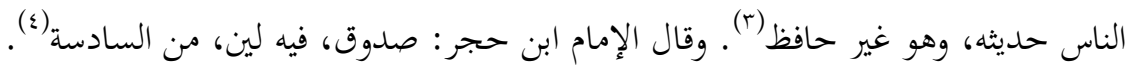

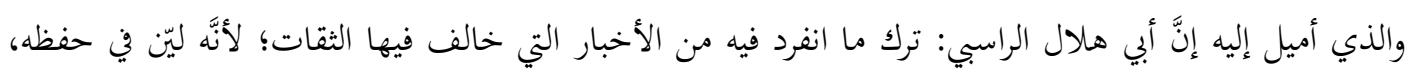

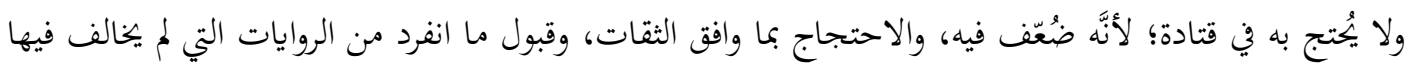

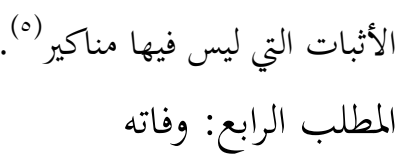

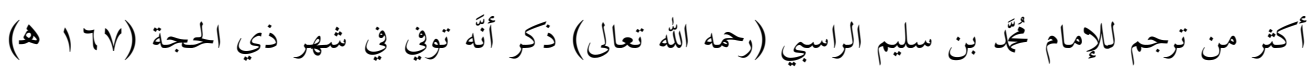

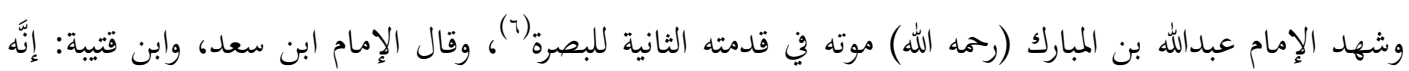

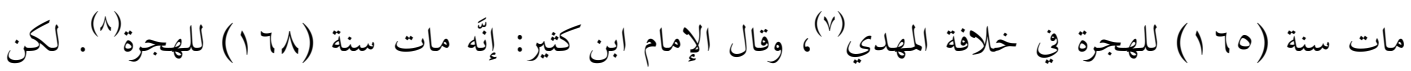

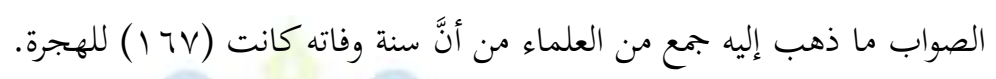

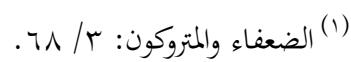

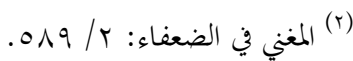

$$
\begin{aligned}
& \text { (r) }
\end{aligned}
$$

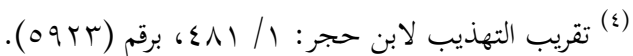

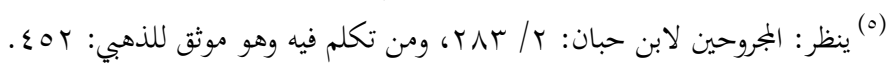

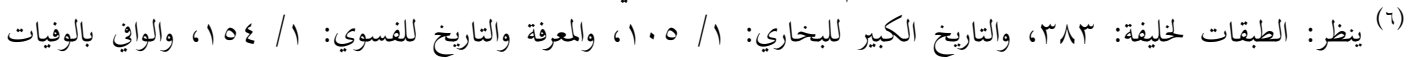

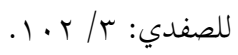

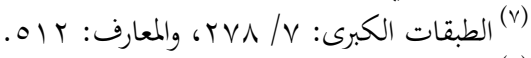

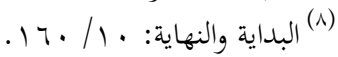

ivo 
أُعل هذا الحديث بعلتين: الأولى: الاختلاف في الرفع والوقف، والثانية: فيمن مزج بين رفعه ووقفه. قال

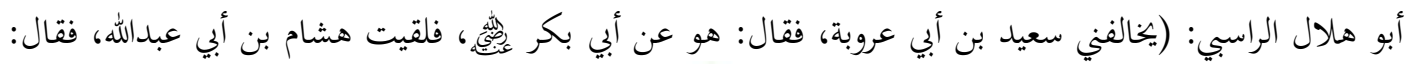

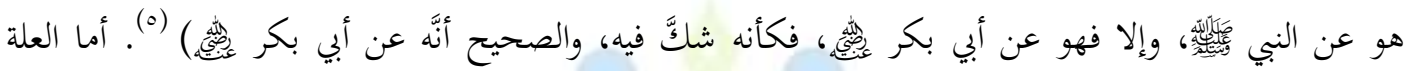

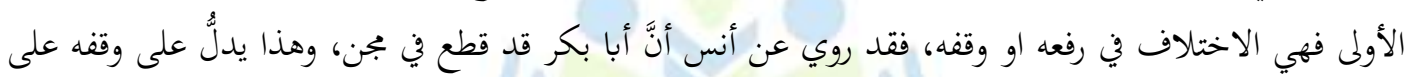

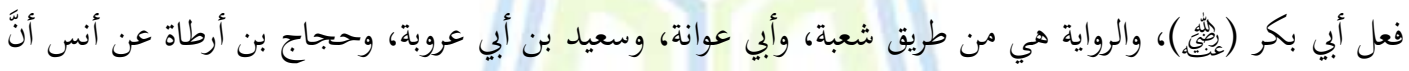

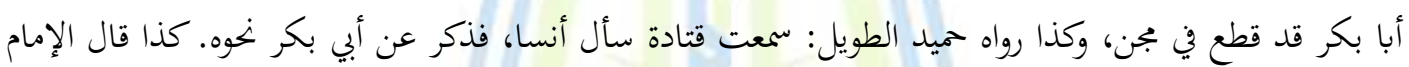

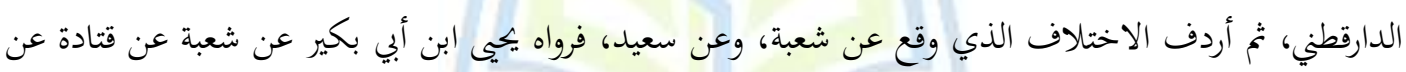
أنس أنَّ النبي

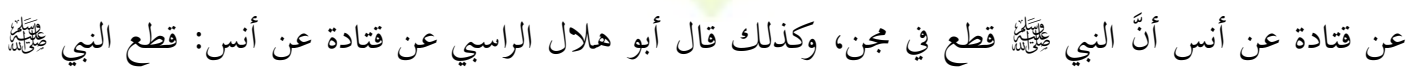

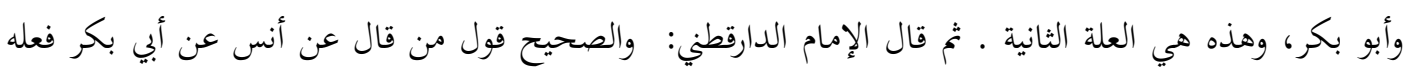

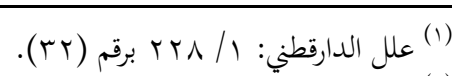

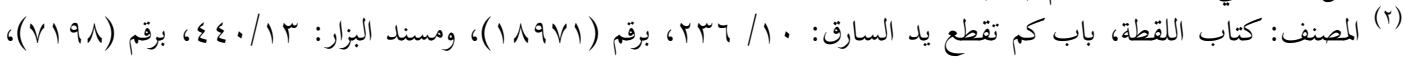

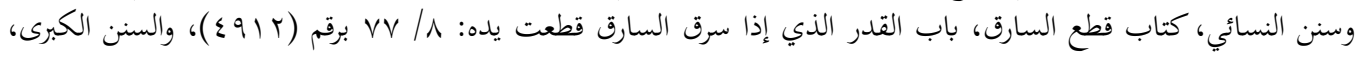

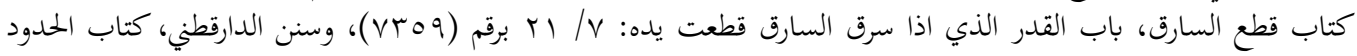

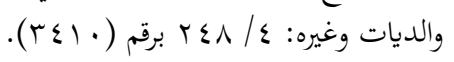

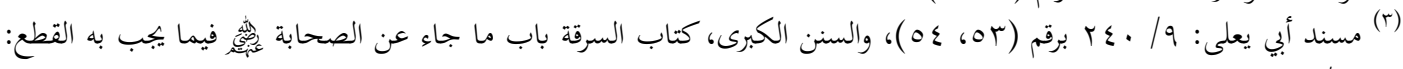

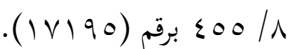

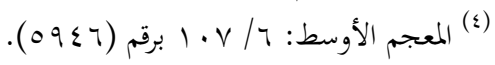

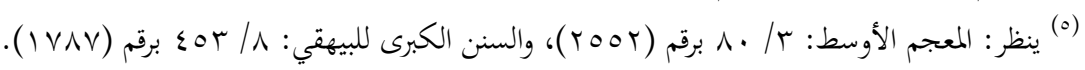

IVT 
غير مرفوع"). وقبل الدارقطني أعلّه الإمام النسائي بعد أنْ أخرج الطريقين الموقوف والمرفوع، ثم قال عقبهما:

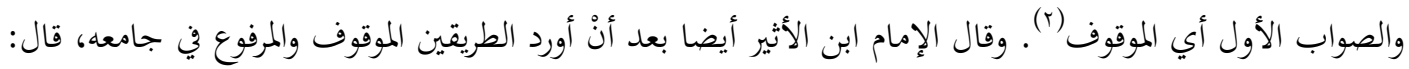

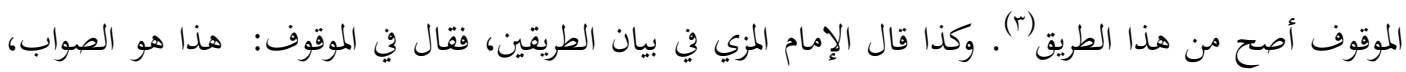

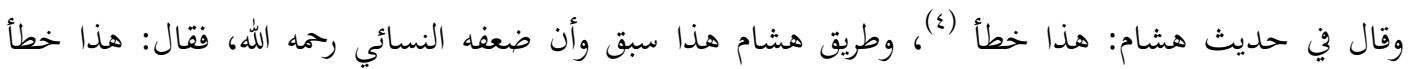

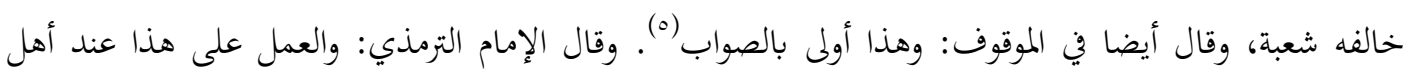

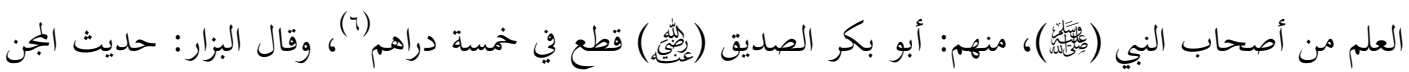

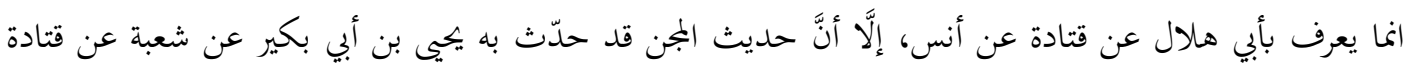

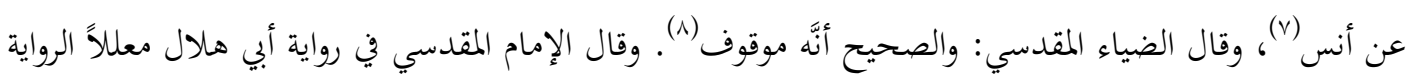

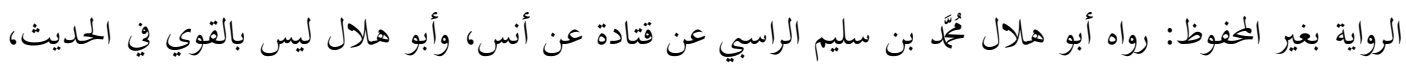

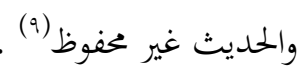
فالصحيح أنَّ الرواية موقوفة في فعل أبي بكر الصديق (ئدئ)، ولا يصح رفعها والله أعلم.

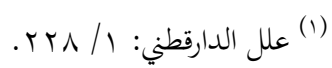

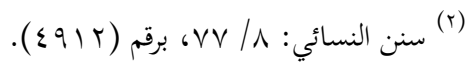

$$
\begin{aligned}
& \text { (r) }
\end{aligned}
$$

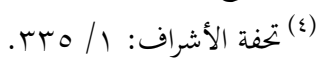

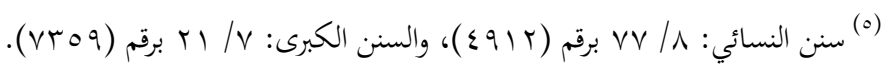

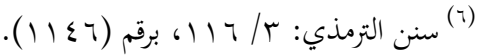

$$
\begin{aligned}
& \text { (v) }
\end{aligned}
$$

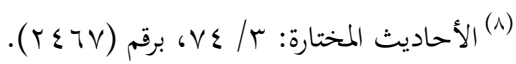

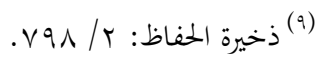




\section{المطلب الثاني: من أكل الثوم فلا يقربن المسجد المّاد}

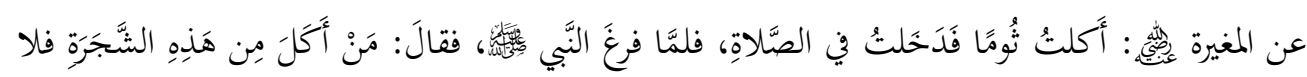

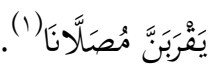

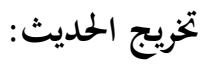

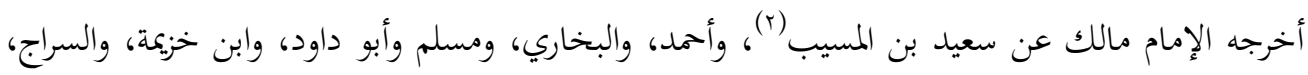

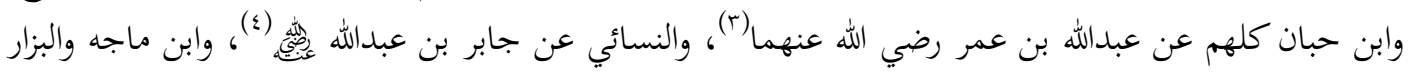

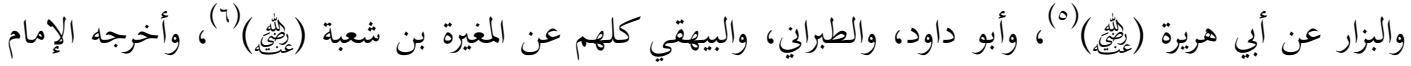

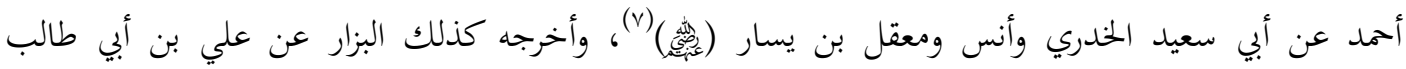
(^) (炭)

الدراسة:

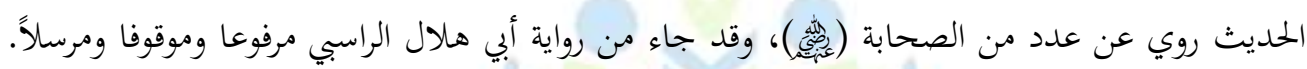

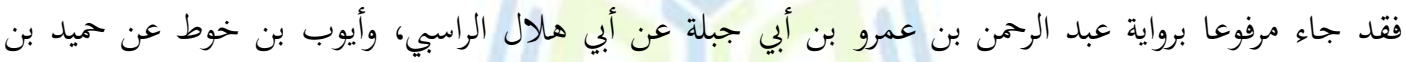

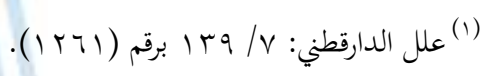

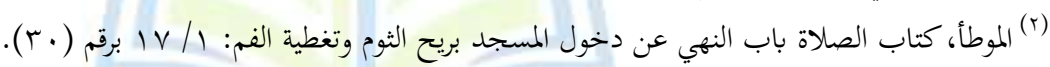

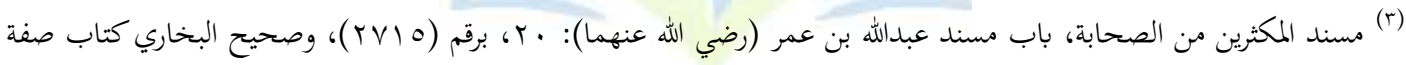

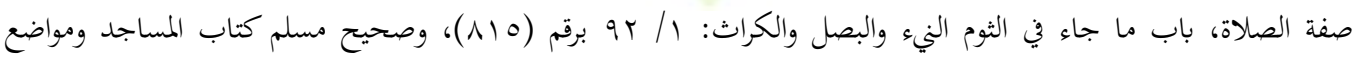

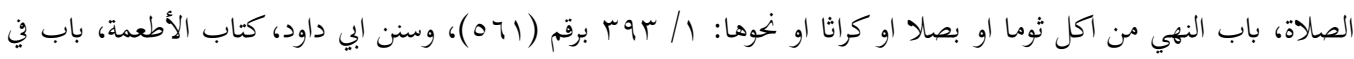

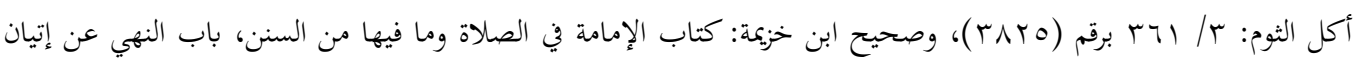

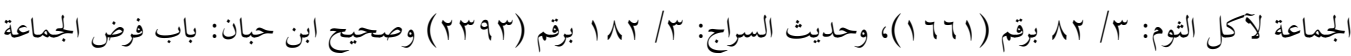

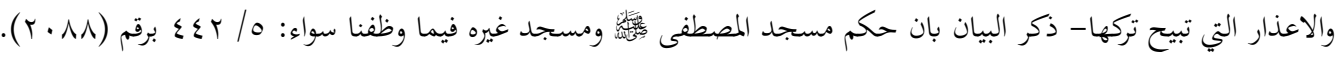

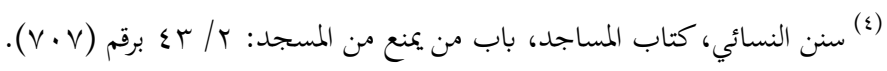

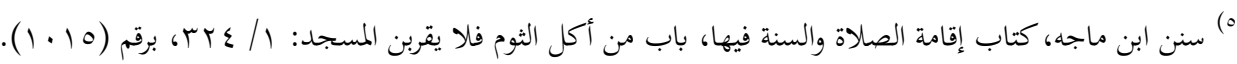

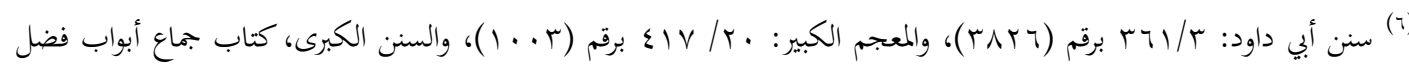

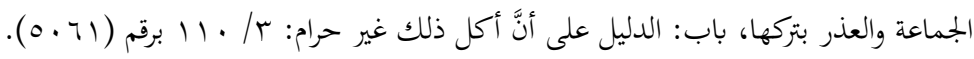

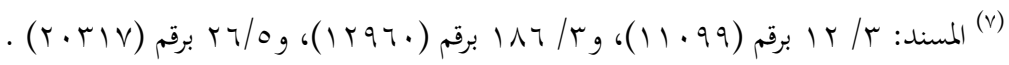

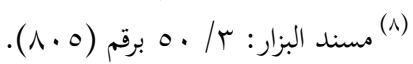

IVA 


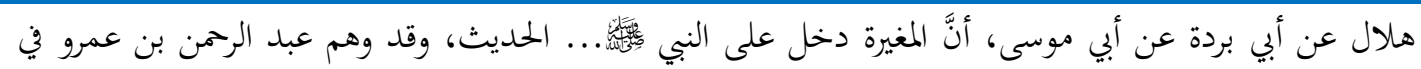

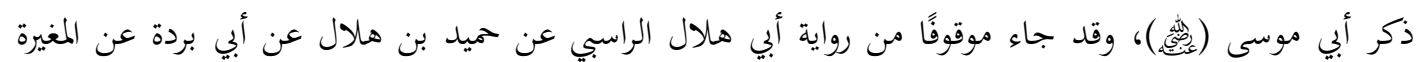

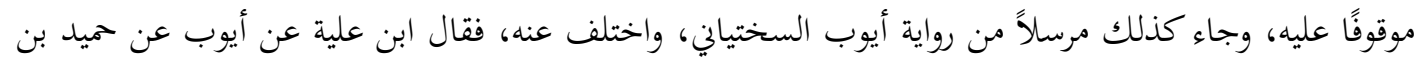

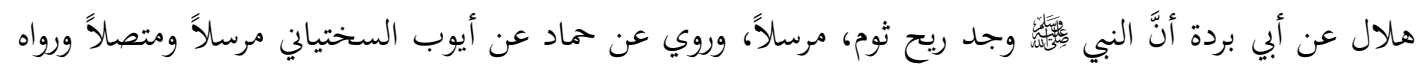

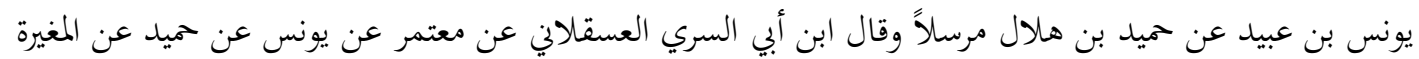

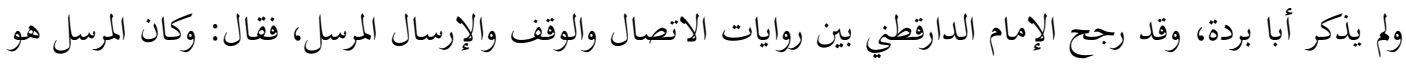

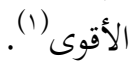

المطلب الثالث: فضل صيام يوم عاشوراء وغيره

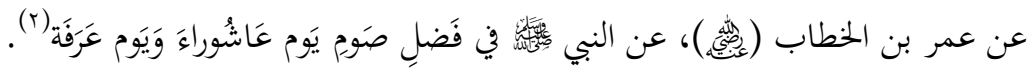
تخريج الحديث:

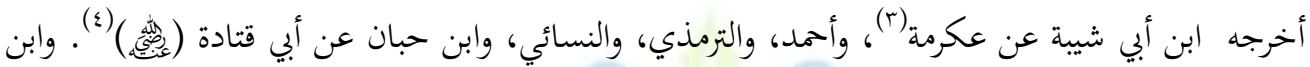

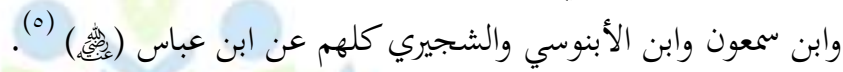

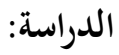

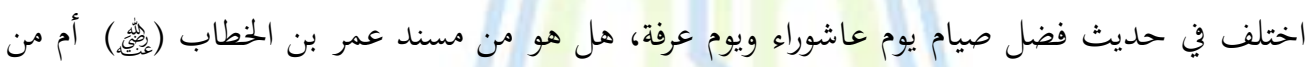

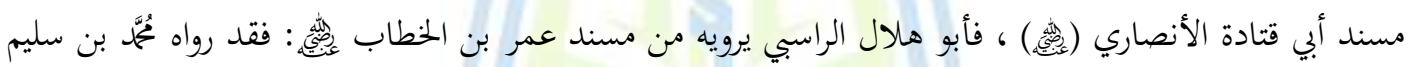

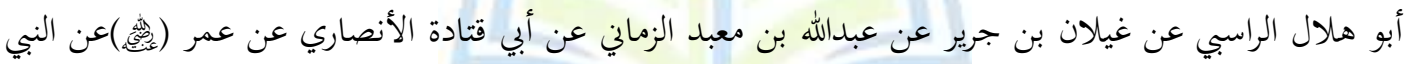

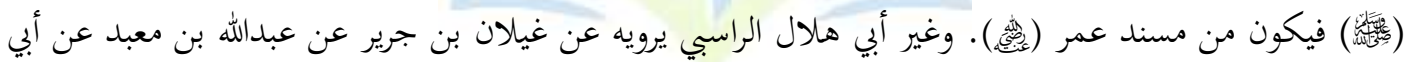

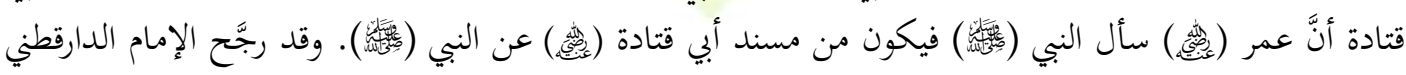

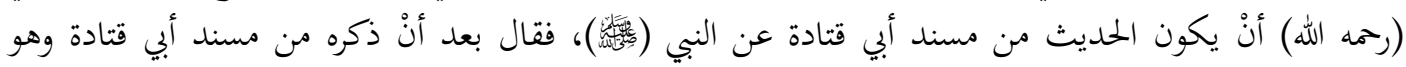

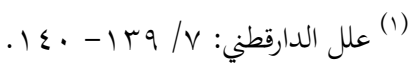

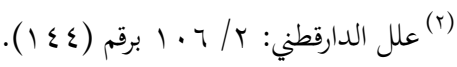

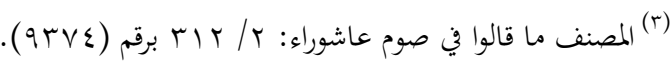

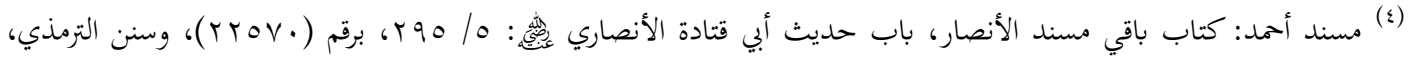

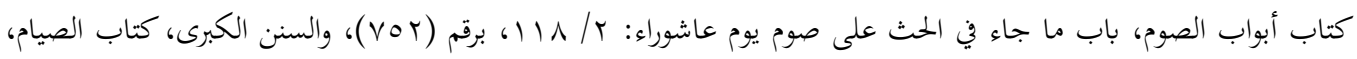

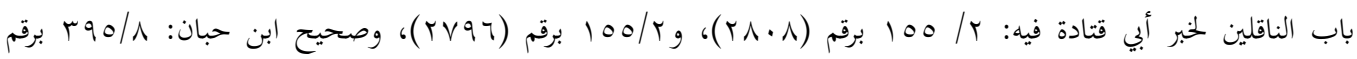

(rtrt)

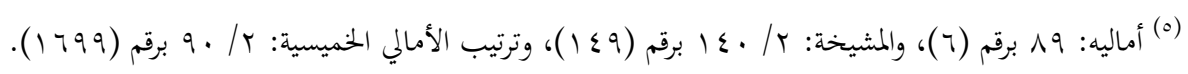

$1 \vee 9$ 


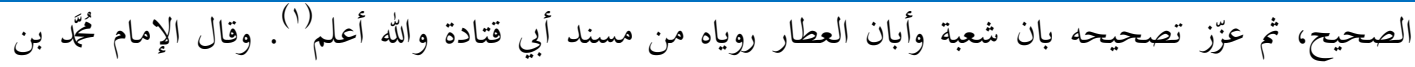

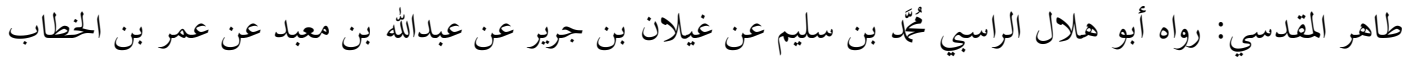

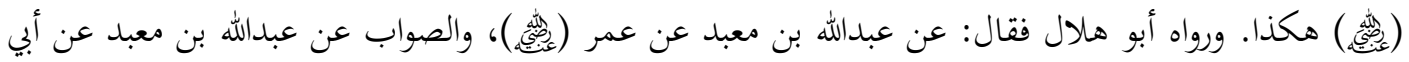

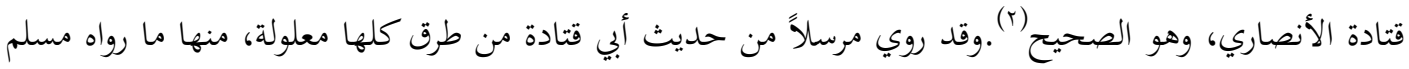

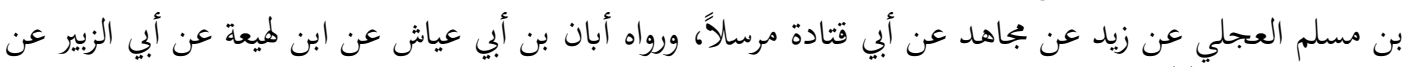

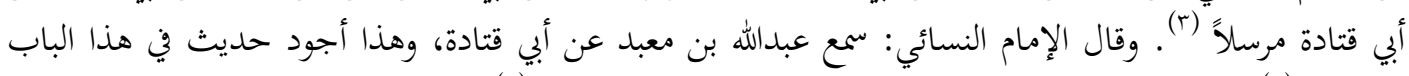

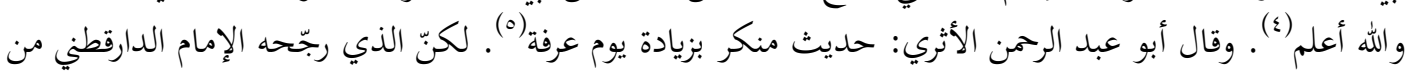

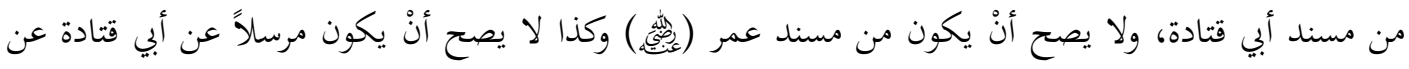
النبي المطلب الرابع: الترغيب في أداء الأمانات

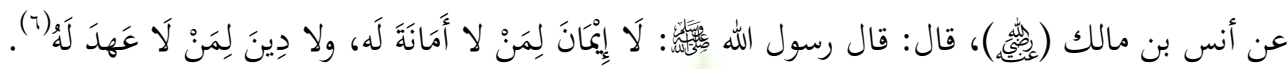

تخريج الحديث: أخرجه ابن أبي شيبة، وأمد، والكشي، والبزار، والمروزي، وأبو يعلى، والخرائطي، وابن حبان،

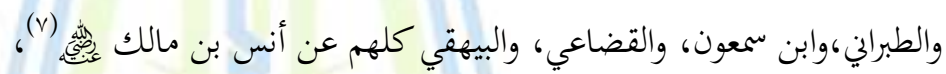

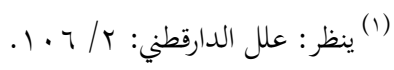

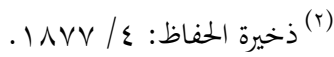

$$
\begin{aligned}
& \text { (r) }
\end{aligned}
$$

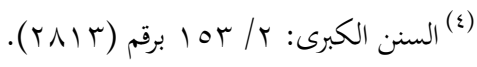

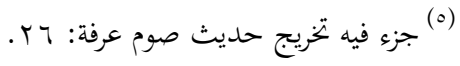

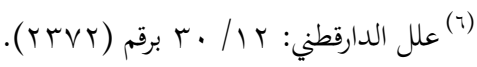

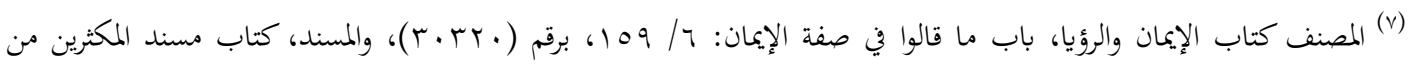

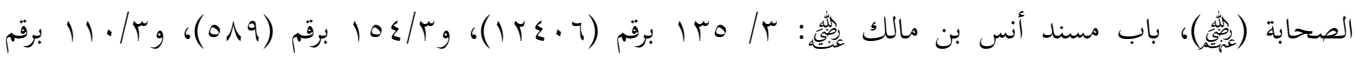

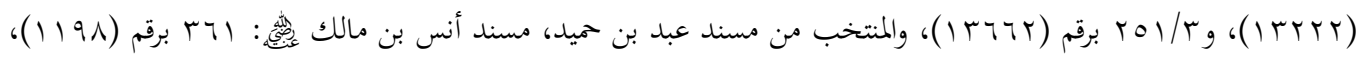

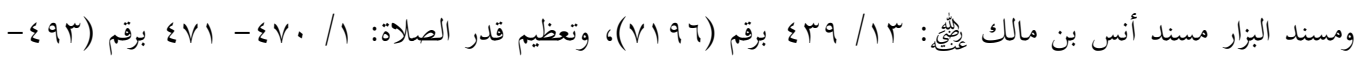

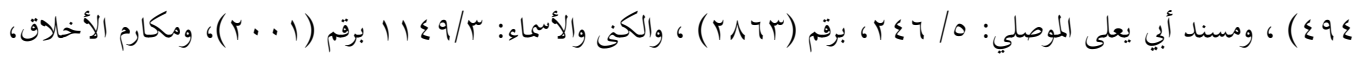

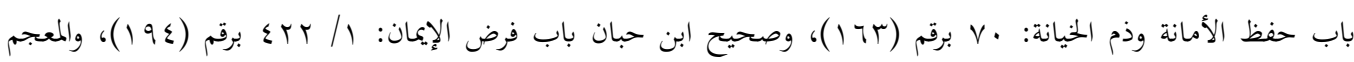
$1 \wedge$. 
الحديث جاء من رواية أبي هلال الراسبي من طريقين: أحدهما متصل، من طريقه عن قتادة عن الحسن عن

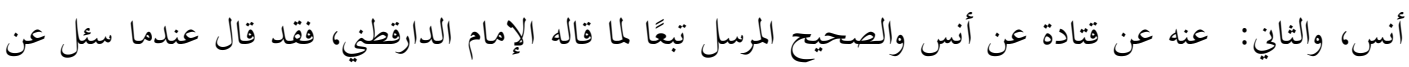

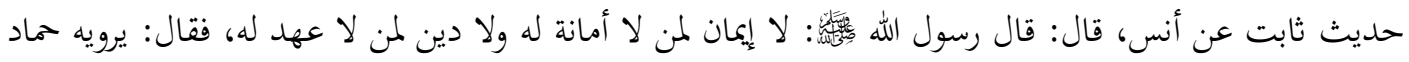

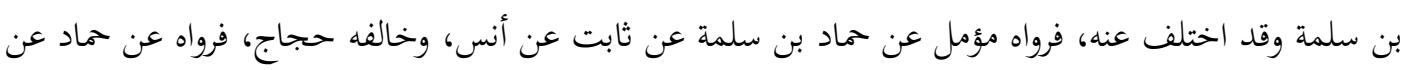

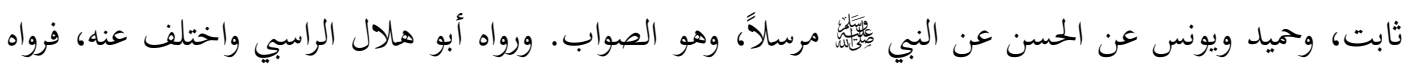

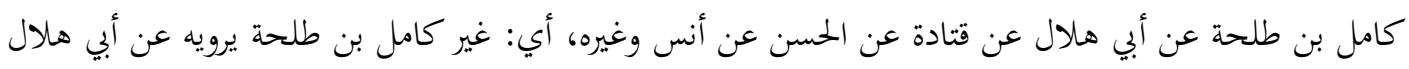

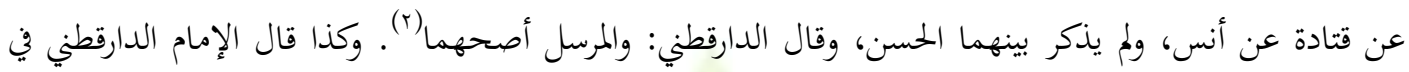

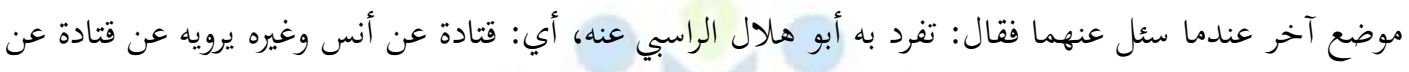

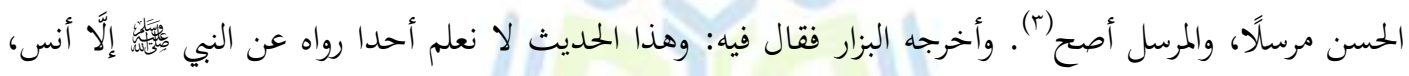

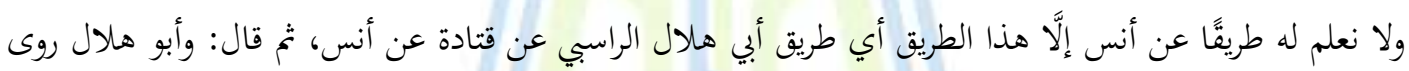

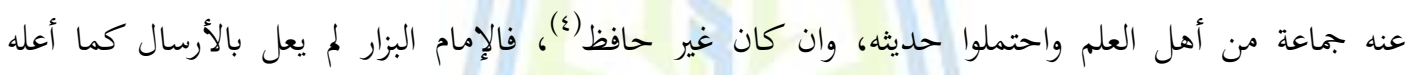

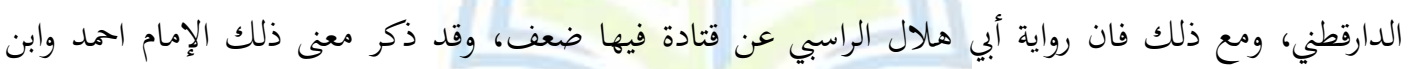

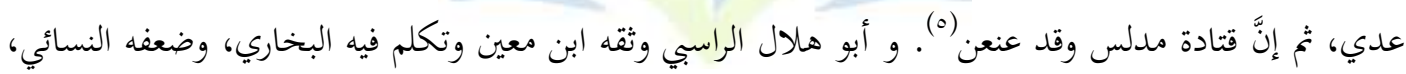

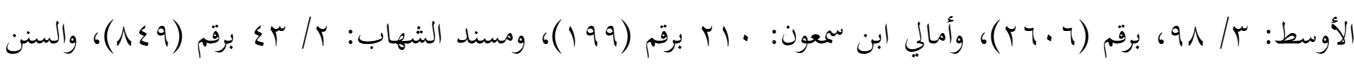

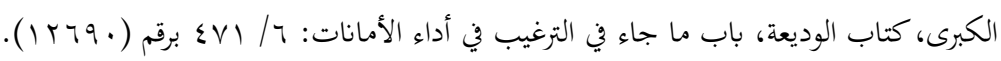

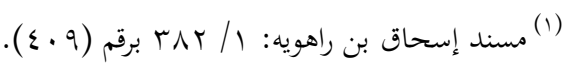

$$
\begin{aligned}
& \text { (r) }
\end{aligned}
$$

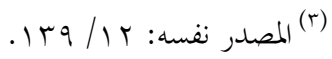

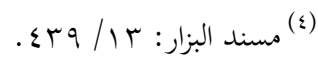

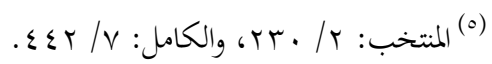

111 


\section{Researcher Journal For Islamic Sciences}

Published by the College of Islamic Sciences at the University of Fallujah

ISSN p.p:2708-3993 / ISSN o.l: 2708-4000

Vol;1- Issue;1/ (2020-2021)

وتلكم في روايته عن قتادة وقال الحافظ ابن حجر: صدوق فيه لين (). فالحديث كما قال الإمام الدارقطني والله أعلم

أصحهما المرسل.

$$
\text { المطلب الخامس: فضل الإمام العادل }
$$

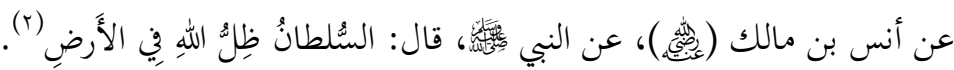

\section{تخريج الحديث:}

أخرجه ابن أبي عاصم، والبيهقي عن أبي بكرة(r)، والبزار والحكيم الترمذي والقضاعي عن ابن عمر رضي الله

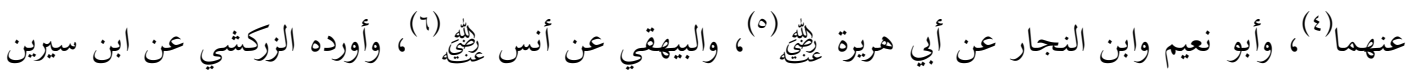
مرفوعًا (v)

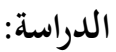

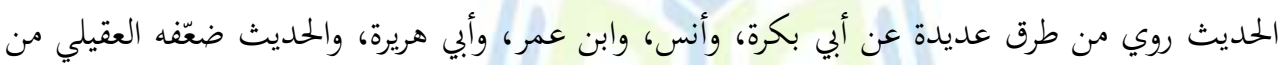

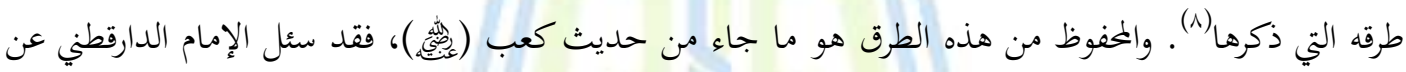

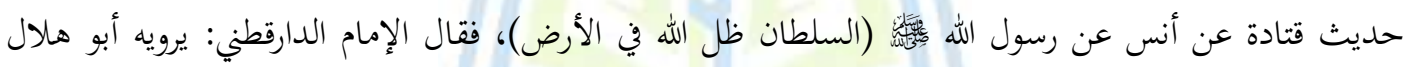

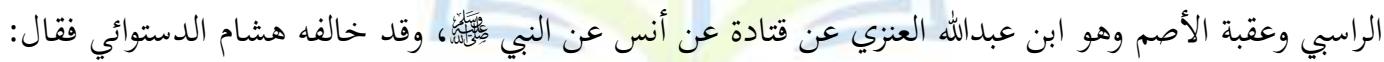

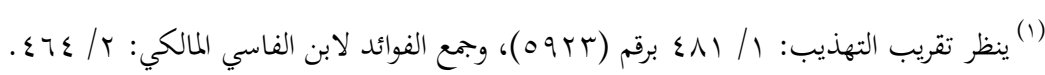

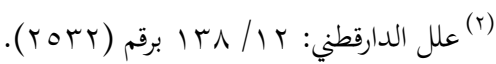

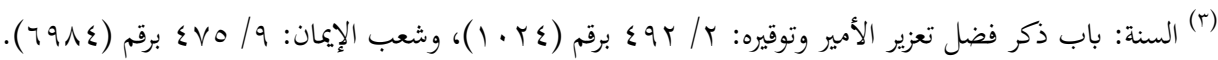

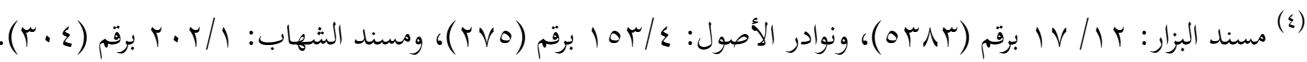

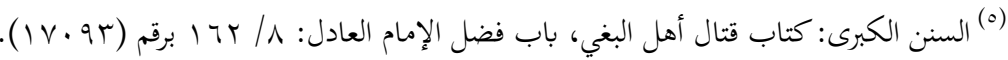

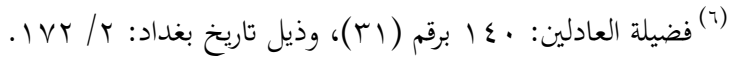

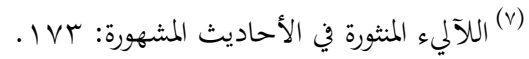

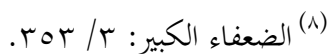

INT 


\section{Researcher Journal For Islamic Sciences}

Published by the College of Islamic Sciences at the University of Fallujah

ISSN p.p:2708-3993 / ISSN o.l: 2708-4000

Vol;1- Issue; 1/ (2020-2021)

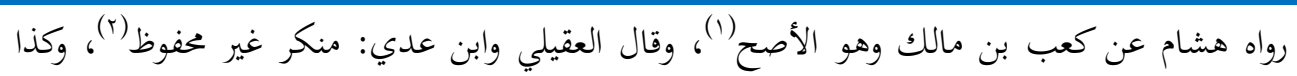

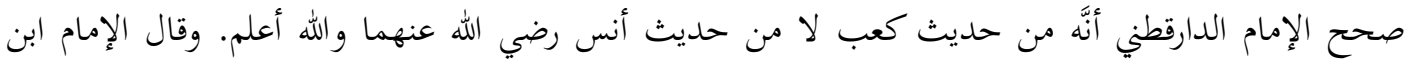

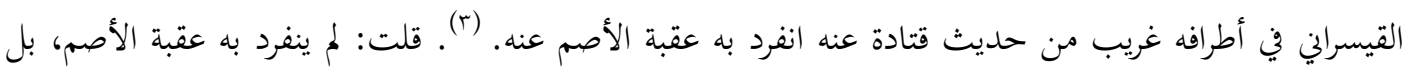
رواه من هو في طبقته كأبي هلال الراسبي.

المطلب السادس: عدد من يدخل بشفاعة النبي ئسئس الجنة

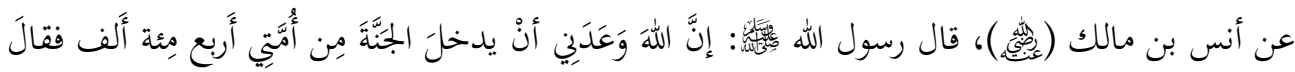

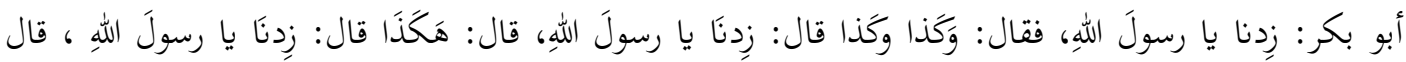

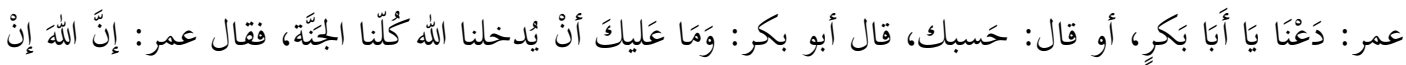

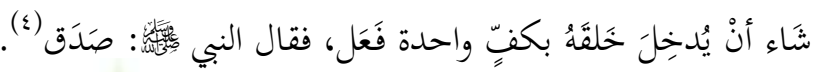
تخريج الحديث: أخرجه الإمام معمر بن راشد، وأحمد، وابن أبي عاصم، وأبو داود السجستاني، والطبراني، والبيهقي، والبغوي، وابن

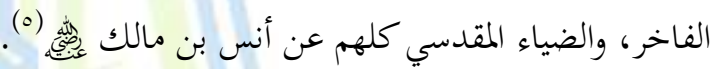

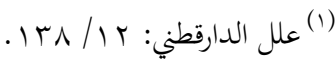

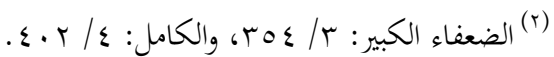

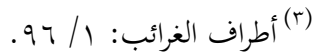

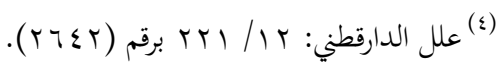

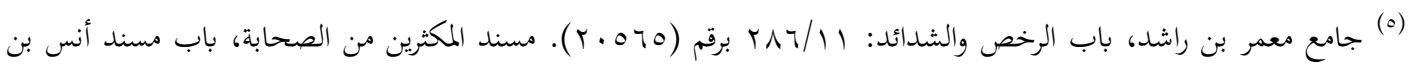

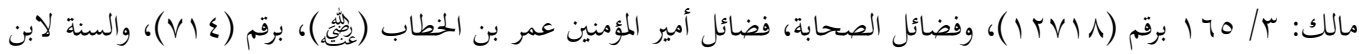

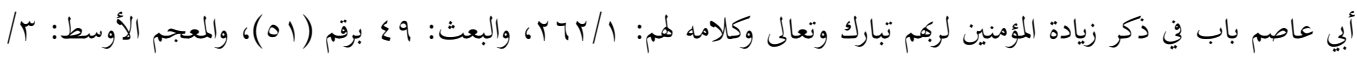

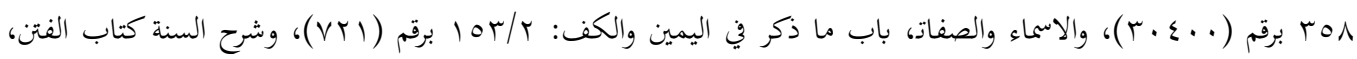

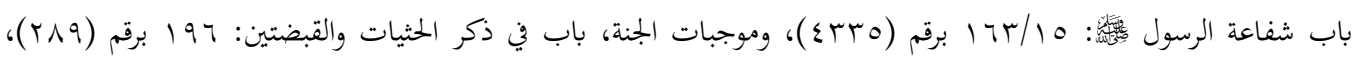

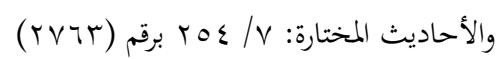

$1 \mathrm{NH}$ 
أعل النقاد حديث أبي بكر الصديق (ئقئّ) من رواية أبي هلال الراسبي بالمخالفة، وقد جاءت المخالفة من

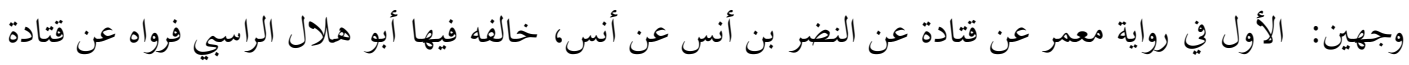

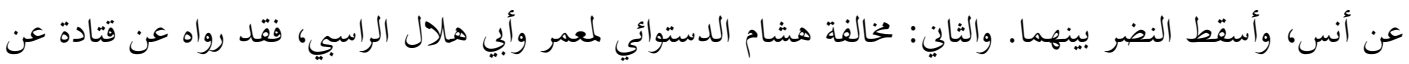

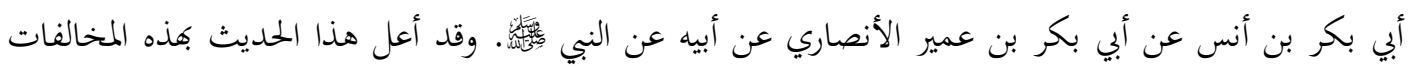

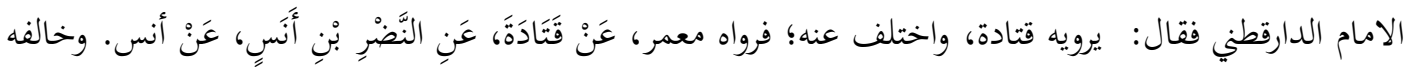

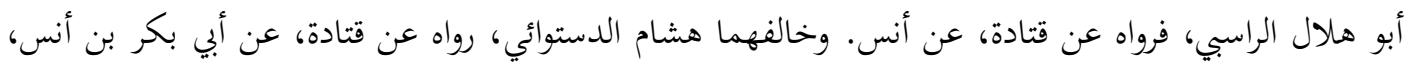

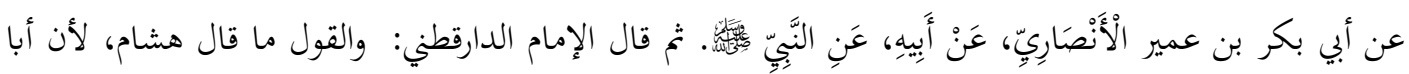

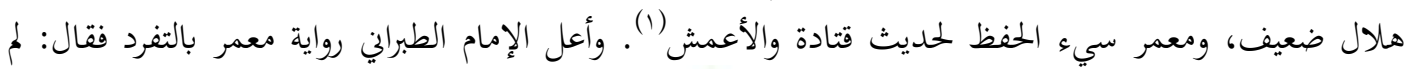

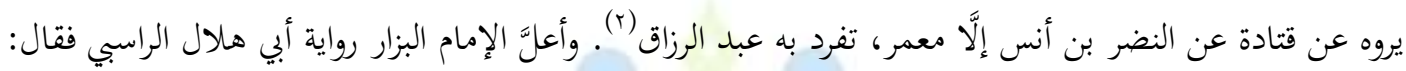

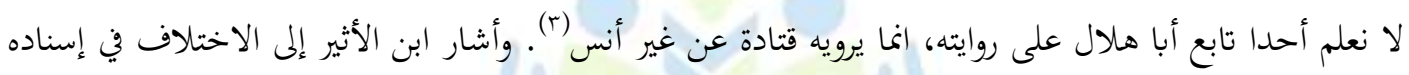

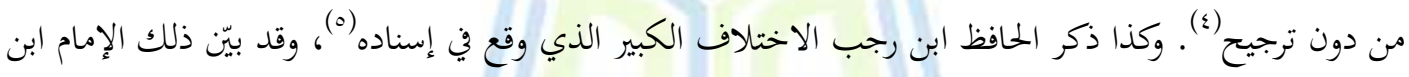

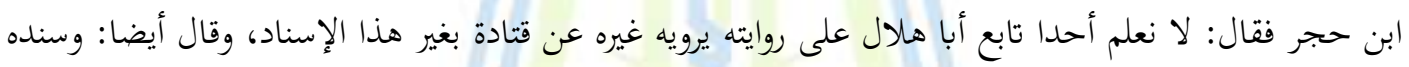

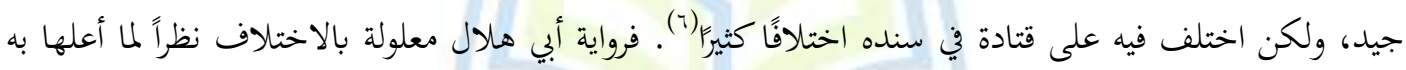
الدارقطني والبزار وغيرها، وان رواية هشام الدستوائي هي الأصح والله أعلم.

$1 \wedge \varepsilon$

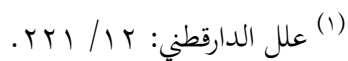

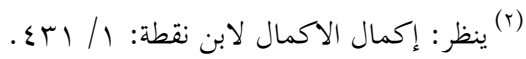

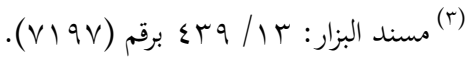

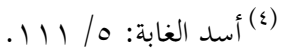

$$
\begin{aligned}
& \text { (0) }
\end{aligned}
$$

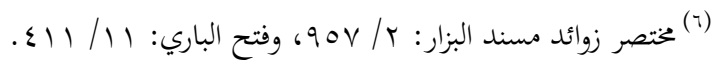




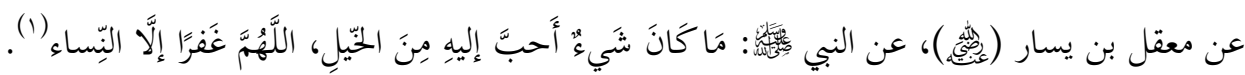

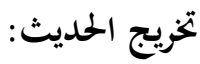

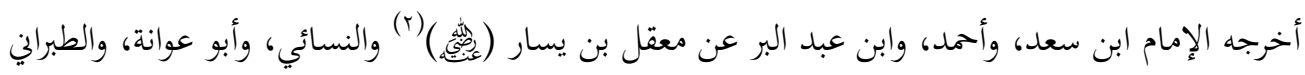

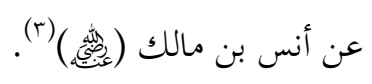

ينظر إلى دراسة هذا الحديث من عدة أوجه: الوجه الأول في رواية أبي هلال الراسبي عن قتادة، والوجه

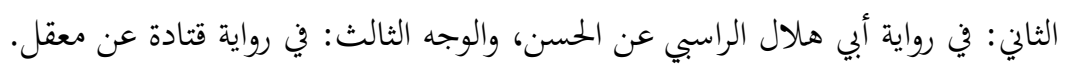

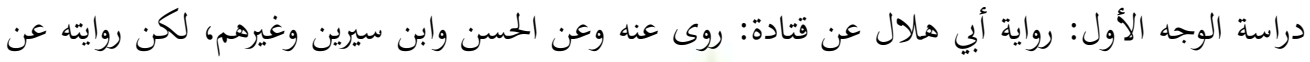

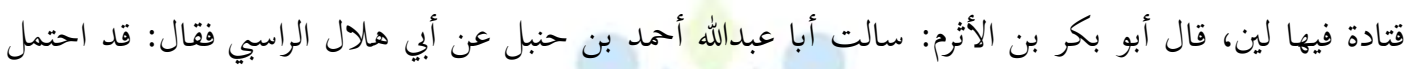

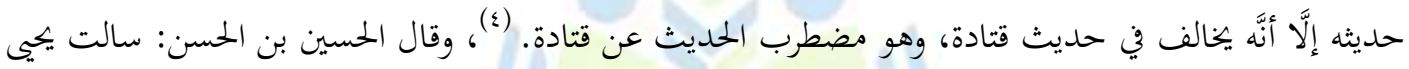

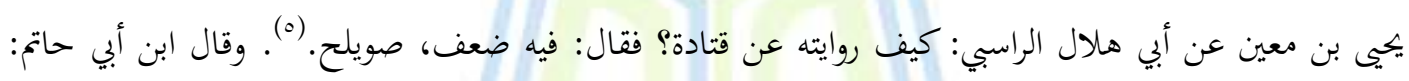

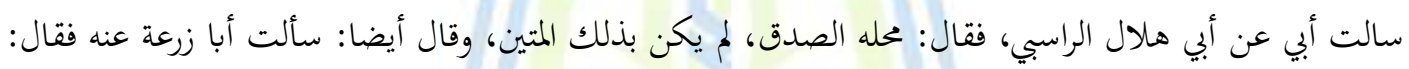

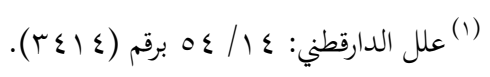

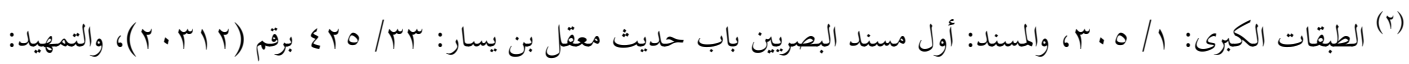

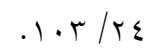

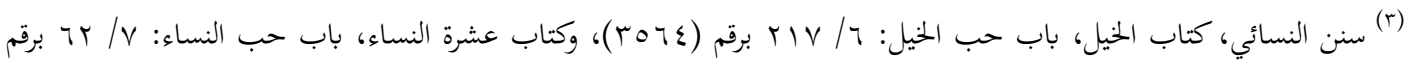

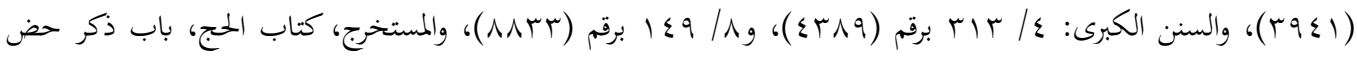

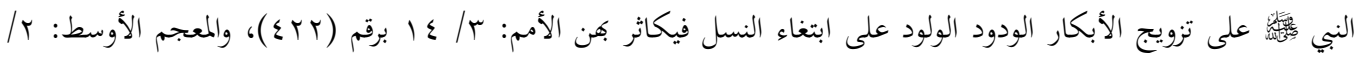

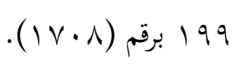

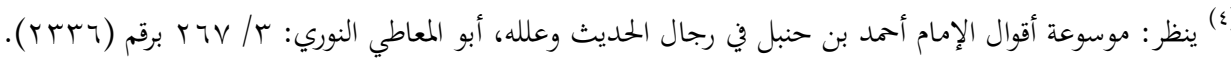

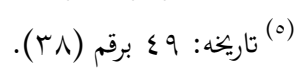

110 
لين(') وقال الحافظ ابن حجر: صدوق فيه لين، واستشهد له الإمام البخاري في القراءة خلف الامام، واخرج له

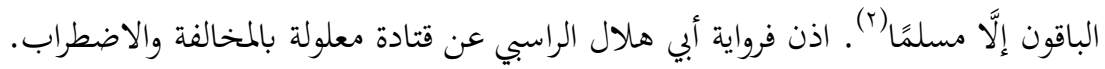

والعلة في دراسة الوجه الثاني: رواية أبي هلال الراسبي للحديث عن قتادة عن الحسن، وقد أخرجها الإمام

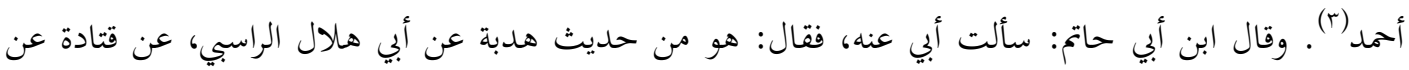

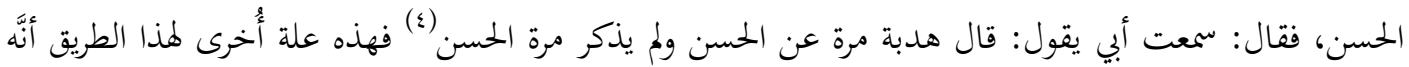
لم يذكر في أي اسانيده عن الحسن والله أعلم.

والعلة في دراسة الوجه الثالث: إنَّ قتادة لم يسمع من معقل، قال ابن أبي حاتم في مراسيله: قال أبو زرعة:

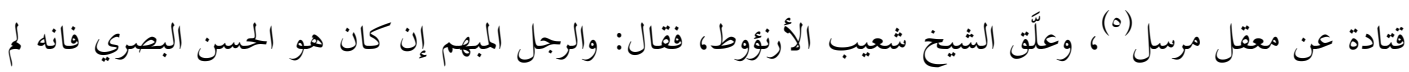

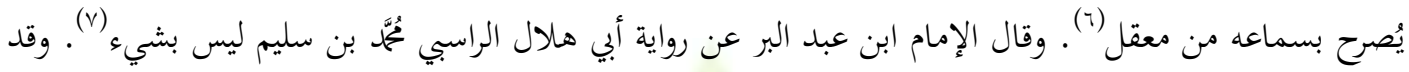

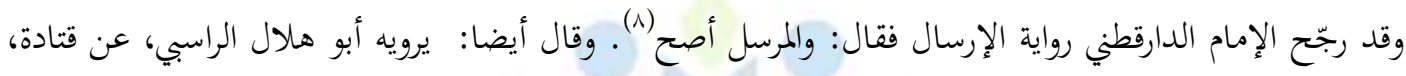

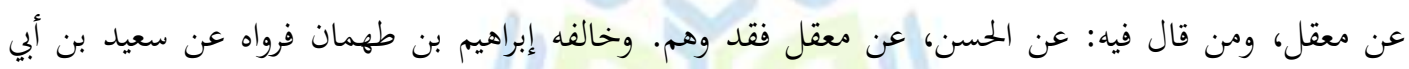

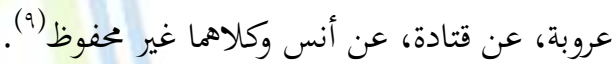

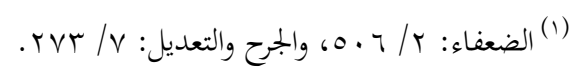

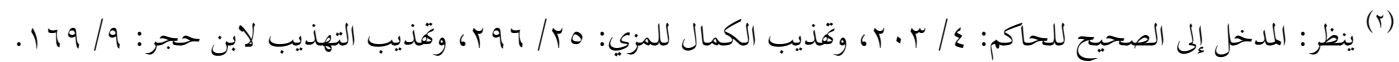

$$
\begin{aligned}
& \text { (r) }
\end{aligned}
$$

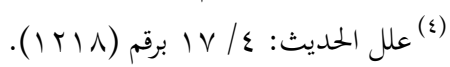

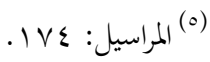

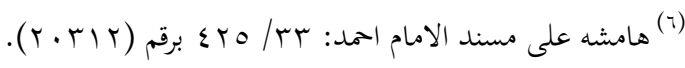

$$
\begin{aligned}
& \text { (v) } \\
& \text { (^) }
\end{aligned}
$$

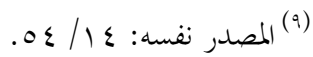

114 
بين ثنايا كتب العلل كانت رحلتي في بيان أهم مرويات الإمام أبي هلال الراسبي التي أعلَّها النُّاد، وقد

$$
\text { خرجت بجملة من النتائج والتوصيات: }
$$

النتائج:

1- إنَّ علم العلل من أصعب علوم الحديث الشريف وأدقها، مما يلزم المشتغلين فيه الدقة في الدراسة والترجيح من خلال القرائن القوية في الحكم، وجمع طرق الحديث وأقوال العلماء رحمهم الله تعلىلى

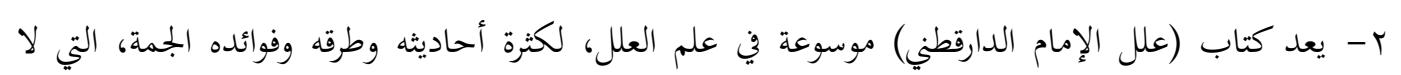
يستغني عنها طالب الحديث.

ب- إنَّ الإمام أبا هلال الراسبي (رحمه الله) من رواة الحديث النبوي الشريف، وقد برز في عصره علماء وأئمة مختصين بهذا الشأن.

ع - إنَّ من شيوخه رمهه الله تعالى: الإمام الحسن البصري، وقتادة، وابن سيرين، وابن ابي مليكة، وغيرهم. ومن

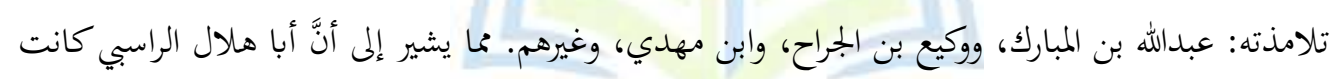
له عناية كبيرة هذذا العلم.

ه- المرويات التي أعلت من خلال كتاب العلل للإمام الدارقطني، فمن العلل منها ما يتعلق بالإسناد، ومنها ما يتعلق بالمتن، ومنها ما يتعلق بكليهما، كرفع موقوف ووصل مرسل، ووهم واختلاف وخطأ، وغيرها. צ- معظم الأحاديث التي أعلت كانت بسببه رممه الله تعالى، لذلك قد أشار النقاد إلى سبب تضعيفهم لمروياته. V - كانت روايات أبي هلال الراسبي عن قتادة مما أجمع النقاد على تضعيفها واضطرابها. 


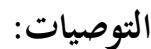

1- الاهتمام بكتاب علل الدارقطني دراسة وتحقيقا بعد ظهور كثير من المخطوطات، وتطور العلم بظهور

$$
\text { وسائل البحث الالكترونية التي تتميز بالسرعة والشمول. }
$$

ץ- الاهتمام بعلم العلل وبكتبه، وبالأجزاء الحديثية، والفوائد، والغرائب، ففيها كثير من المرويات التي تفيد في

$$
\text { الترجيح عند الاختلاف بين الروايات الحديثية. }
$$




\section{المصادر والمراجع}

القران الكريم

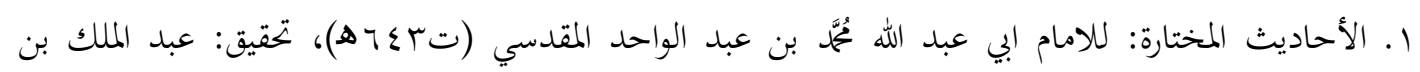

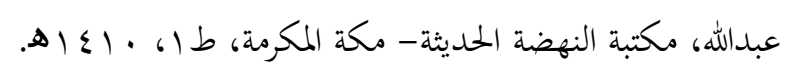

r. الاستغناء في معرفة المشهورين من حملة العلم بالكنى: للإمام ابي عمر يوسف بن عبد الله بن عبد البر القرطبي(ت آحهـ)، تحقيق: عبد الله مرحول السوالمة، المملكة العربية السعودية - الرياض، طا، 019 ام. r. الأسماء والصفات: للإمام ابي بكر أمد بن الحسين بن علي الخراساني، البيهقي (ت 01؛ هـ)، حققه وخرج أحاديثه وعلق عليه: عبد الله بن مُمّم الحاشدي، مكتبة السوادي، جدة ، طا ، به9 ام.

ع. أطراف الغرائب والأفراد: للامام أبي الفضل مُحة بن طاهر بن علي بن أممد المقدسي ، المعروف بابن القيسراني

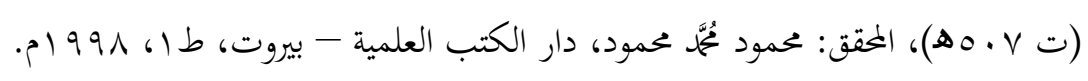

ه. إكمال تذذيب الكمال في أسماء الرجال: العلامة علاء الدين مغلطاي (ت: YTV ه)، تحقيق: أبي عبد الرمن

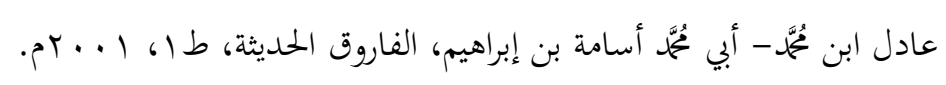

آ. الأمالي : للإمام ابي الحسن يُّة بن أمد بن إسماعيل بن عنس البغدادي المعروف بابن سمعون الواعظ (ت  119 


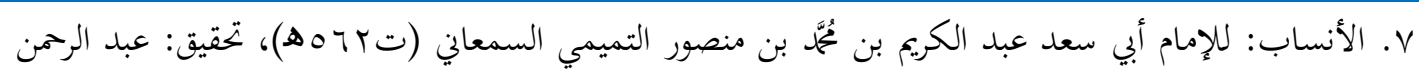
بن يميى المعلمي اليماني وغيره، بجلس دائرة المعارف العثمانية، حيدر آباد، ط ا، بالج 97 م.

A. البعث: للإمام أبي بكر بن أبي داود، عبد الله بن سليمان بن الأشعث الأزدي السجستاني (ت 7 ابهـ)، تحقيق: أبو هاجر مُحمّم السعيد بن بسيوني زغلول، دار الكتب العلمية، بيروت - لبنان، طا، 9NV ام. 9. تاريخ ابن معين (رواية عثمان الدارمي): للإمام أبي زكريا يهيى بن معين بن عون البغدادي (ت بrابه)، تحقيق: د. أحمد يُمَّمَ نور سيف، دار المأمون للتراث- دمشق.

• ا. التاريخ الكبير: للإمام أبي عبد الله مُحَّم بن إسماعيل بن إبراهيم البخاري الجعفي (ت7ه به)، تحقيق: السيد. هاشم الندوي، دار الفكر.

11 ا. تحفة الأشراف بمعرفة الأطراف: للامام أبي الحجاج يوسف بن عبد الرمن المزي (ت rع هـ)تقيق: عبد الصمد شرف الدين، المكتب الإسلامي، والدار القيّمة، طץ، بمج ام.

rا. ترتيب الأمالي الحميسية للشجري: مؤلف الأمالي: يهيى (المرشد بالل) بن الحسين (الموفق) بن إسماعيل بن زيد

الحسني الشجري الجرجاني (ت99؛ هـ)، رتبها: القاضي محيي الدين يُحَّمُ بن أحمد القرشي العبشمي (ت

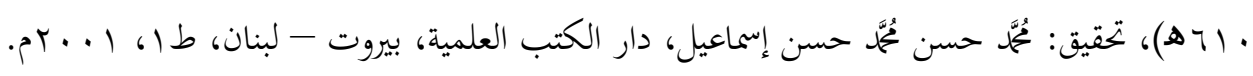

rا ا. التعديل والتجريح: للإمام أبي الوليد سليمان بن خلف بن سعد بن أيوب بن وارث التجبي القرطبي الباجي الأندلسي (ت ع \& هـ)، تحقيق: د. أبو لبابة حسين، دار اللواء للنشر والتوزيع- الرياض، طا، 719 ام. 19. 
ع ا. تقريب التهذيب: للإمام أبي الفضل أحمد بن علي بن حجر العسقلاني (ت (ت10ه)، تحقيق: مصطفى عبد

$$
\text { القادر عطا، دار الكتب العلمية، بيروت- لبنان، طا، ب99 ام. }
$$

هـ التمهيد لما في الموطأ من المعاني والأسانيد: للإمام أبي عمر يوسف بن عبدالله بن عُمَّمَ بن عبدالبر بن عاصم النمري القرطبي (ت بآ ـه)، تحقيق: مصطفى بن أحمد العلوي ومُحمّم عبد الكبير البكري، وزارة عموم الأوقاف

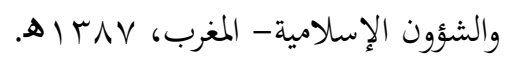

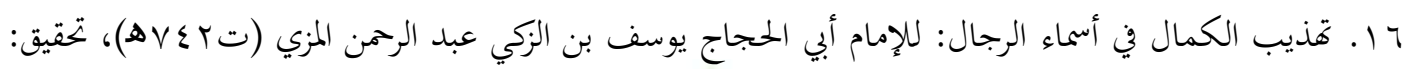

$$
\text { د. بشار عواد معروف، مؤسسة الرسالة-بيروت، ط |، ـ191 م. }
$$

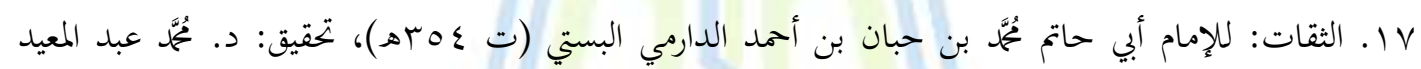
خان، دائرة المعارف العثمانية بحيدر آباد الدكن- الهند، ط ا، بلو ام.

11. الجامع (منشور كملحق بمصنف عبد الرزاق) للإمام ابي عروة معمر بن أبي عمرو راشد الأزدي مولاهم، البصري، نزيل اليمن (ت به اهـ)، تحقيق: حبيب الرحمن الأعظمي المجلس العلمي بباكستان، وتوزيع المكتب

$$
\text { الإسلامي ببيروت، طץ، r. أهـ اله. }
$$

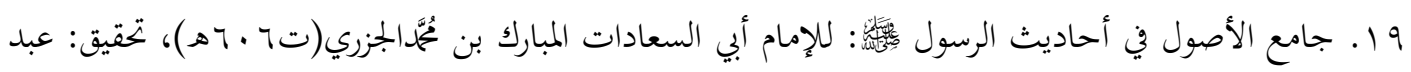
القادر الأرناؤوط، مكتبة الحلواني، ومطبعة الملاح، طا 1، 19Vام. 


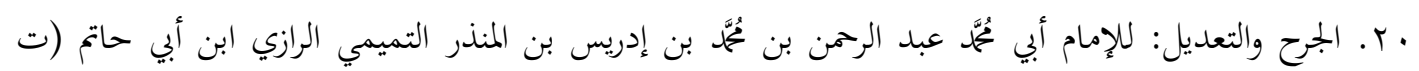

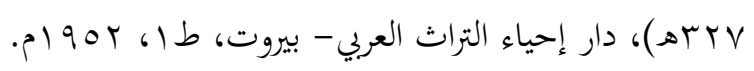

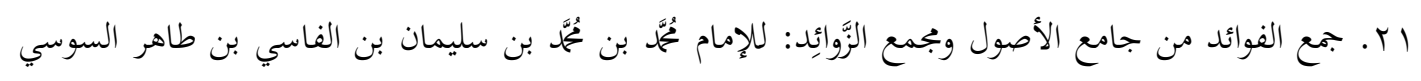

الردواني المغربي المالكي (ت ؟9 ـ اهـ)، تحقيق وتخريج: أبو علي سليمان بن دريع، مكتبة ابن كثير، الكويت -

$$
\text { دار ابن حزم، بيروت، ط ا، } 991 \text { ام. }
$$

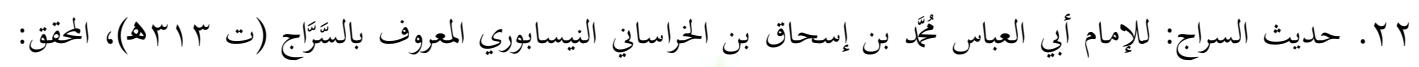
أبو عبدالله حسين بن عكاشة، تخريج: زاهر بن طاهر الشحامي، الفاروق الحديثة للطباعة والنشر، ط ا، ع . ب م.

بr. ذخيرة الحفاظ: للإمام أبي الفضل يُمَّمَ بن طاهر المقدسي ، المعروف بابن القيسراني (ت V.0هـ) المققق: د.

$$
\text { عبد الرمن الفريوائي دار السلف - الرياض، ط1، } 1997 \text { ام. }
$$

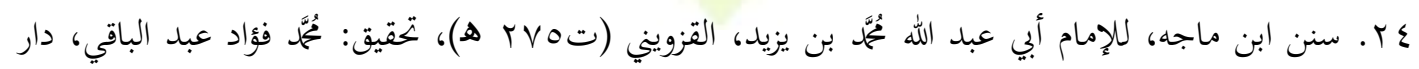

$$
\text { الفكر - بيروت. }
$$

Or. سنن أبي داود: للإمام أبي داود سليمان ابن الأشعث السجستاني الأزدي (ت TVOه)، تحقيق: الشيخ خليل

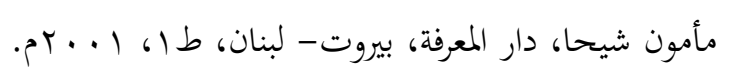

بr. السنن الكبرى: للإمام أبي عبد الرحمن أحمد بن شعيب الخراساني النسائي (تr.rه))، تحقيق: حسن عبد

$$
\text { المنعم شبي، مؤسسة الرسالة- بيروت، ط 1، 1. ب بم. }
$$

195 
VV Tؤالات ابن الجنيد لأبي زكريا يميى بن معين: للإمام أبي زكريا يهيى بن معين ابن عون بن عبد الرمن المري،

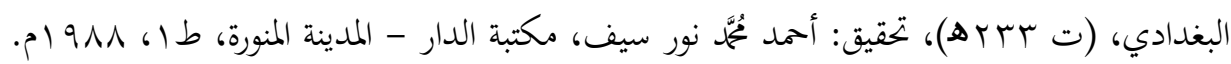

^r. سؤالات أبي عبيد الآجري أبا داود السجستاني في الجرح والتعديل: للإمام أبي داود سليمان بن الأشعث بن

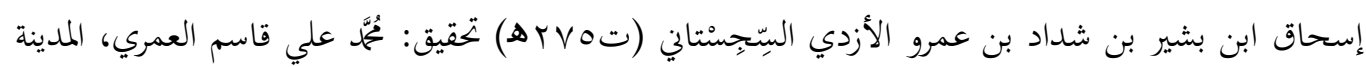

$$
\text { المنورة، ط ا، بما9 ام. }
$$

وج. شعب الإيمان: للإمام أبي بكر احمد بن الحسين بن علي البيهقي (تمهءه)، تحقيق: د. عبد العالي عبد

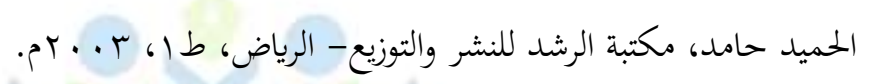

•r. صحيح ابن حبان: للإمام ابي حاتم مُحمّة بن حبان بن احمد التميمي البستي ت(عهبه)، تققيق: شعيب

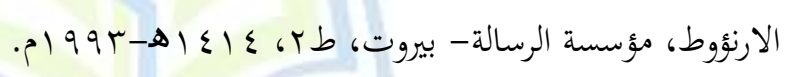

اس. صحيح ابن خزيمة: للإمام أبي بكر يُمَّمَ بن إسحاق بن خزيمة بن المغيرة بن صالح بن بكر السلمي النيسابوري

$$
\text { (ت ا البهر)، تحقيق: د. مُحمّم مصطفى الأعظمي، المكتب الإسلامي- بيروت. }
$$

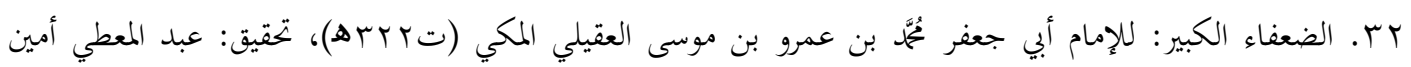

$$
\text { قلعجي، دار المكتبة العلمية- بيروت، طا ، ع } 91 \text { ام. }
$$

بr. الضعفاء والمتروكون: للإمام أبي الفرج عبد الرمن ابن علي بن يُمَّمَ الجوزي (تVوهه)، تحقيق: عبد الله

$$
\text { القاضي، دار الكتب العلمية- بيروت، ط(1)، } 7 \text { •ــ اهـ. }
$$

194 
ع r. الضعفاء والمتروكون: للإمام أبي عبد الرمن أحمد بن شعيب بن علي النسائي (ت r.rاه)، تحقيق: محمود

$$
\text { إبراهيم زايد، دار الوعي- حلب، ط 1، } 94 \text { باهـ. }
$$

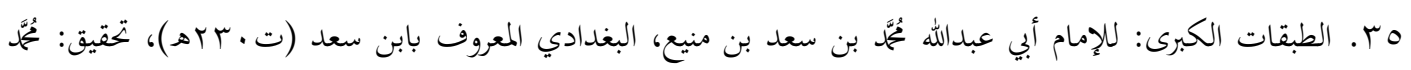
عبدالقادر عطا، دار الكتب العلمية-بيروت، طا، ـ99 موم.

بس. الطبقات خليفة بن خياط: للإمام أبي عمرو خليفة بن خياط بن خليفة الشيباني العصفري البصري (ت

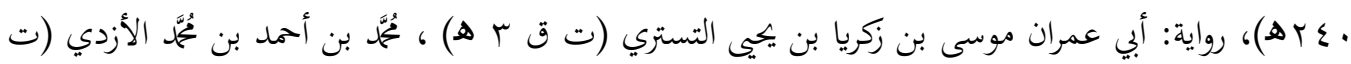
ق ب هـ)، المحقق: د سهيل زكار، دار الفكر للطباعة والنشر والتوزيع، ب99 ام.

V r. العلل الواردة في الأحاديث النبوية: للإمام أبي الحسن علي بن عمر بن أحمد الدارقطني (تمربه)، تحقيق وتخريج: محفوظ الرمن زين الله، دار طيبة-الرياض، ط 1، 911 ام.

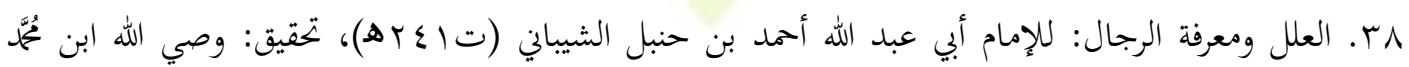

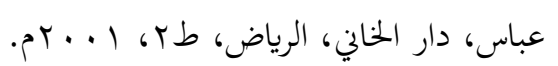

وَr. فتح الباري شرح صحيح البخاري: للإمام أبي الفرج عبد الرحمن بن شهاب الدين البغدادي الشهير بابن رجب (ت 90 هـ)، تحقيق: طارق بن عوض الله، دار ابن الجوزي- السعودية، طץ.

•ــ. الكامل في ضعفاء الرجال: للإمام أبي أحمد عبد الله بن عدي الجرجاني (ت هبrهـ)، تحقيق: عادل أحمد عبد الموجود، علي مُحَّم معوض وعبد الفتاح أبو سنة، الكتب العلمية، بيروت- لبنان، طا، لو99 ام. $19 \varepsilon$ 
اءــ كتاب الضعفاء لأبي زرعة الرازي وجهوده في السنة النبوية: للإمام أبي زرعة عبيد الله ابن عبد الكريع بن الرازي (ت ع ب اهـ)، رسالة ماجستير: لسعدي بن مهدي الهاشي، المدينة النبوية، المملكة العربية السعودية، ب 91 ام.

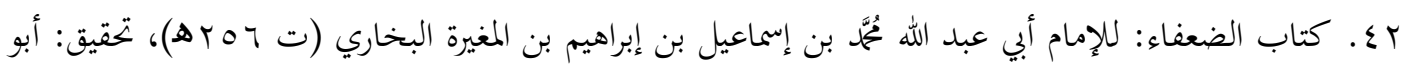
عبدالله أحمد بن إبراهيم بن أبي العينين، مكتبة ابن عباس، ط ا، ه . . ب م.

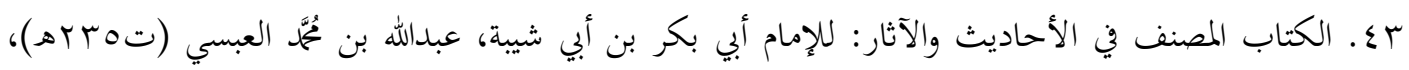
تحقيق: كمال يوسف الحوت، مكتبة الرشد-الرياض، ط ا، 9 .ـ اهـ.

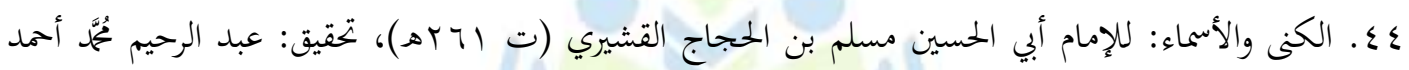
القشقري، الجامعة الإسلامية- المدينة المنورة، طا، ع191 ام.

هـ. لب اللباب في تحرير الأنساب: للإمام عبد الرحمن بن أبي بكر، جلال الدين السيوطي (ت 119ه) ، دار صادر - بيروت.

كاء. المجتى من السنن (سنن النسائي)، لأبي عبد الرممن أحمد بن شعيب بن علي الخراساني، النسائي (ت

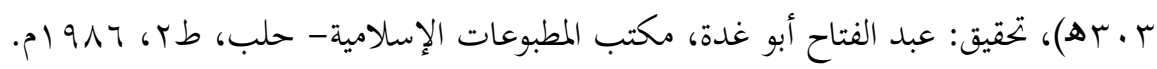

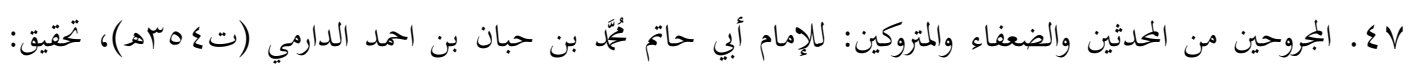
محمود إبراهيم زايد، دار الوعي- حلب، ط1، 97 اهـ. 
1ـ. مستخرج أبي عوانة: للإمام يعقوب بن إسحاق بن إبراهيم النيسابوري الإسفراييني (ت: ب اباهد)، تحقيق: أيمن بن عارف الدمشقي، دار المعرفة-بيروت، ط 1، 991 1م.

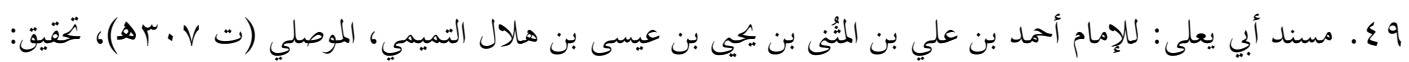

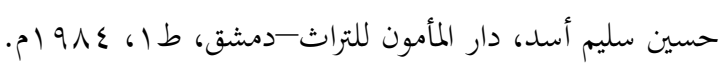

• 0 . مسند اسحاق بن راهويه: للامام اسحاق بن ابراهيم بن مخلد المروزي (تمرrهاه)- تحقيق: الدكتور عبد الغفور عبد

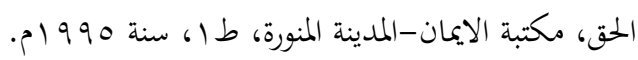

اه. مسند البزار المشهور باسم البحر الزخار: للإمام أبي بكر أحمد بن عمرو بن عبد الخالق المعروف بالبزار

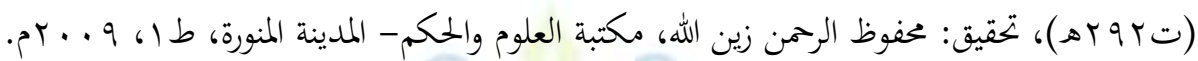

ro مسند الشهاب: للإمام أبي عبد الله مُحّمّ بن سلامة بن جعفر بن علي بن حكمون القضاعي المصري (ت

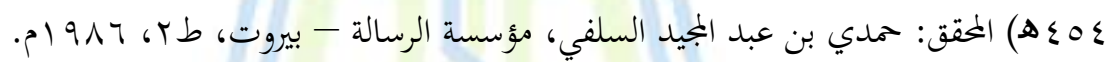

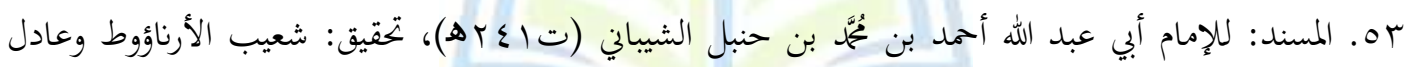

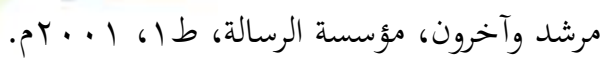

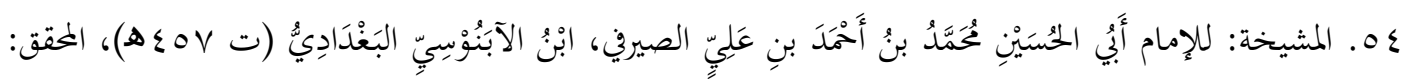

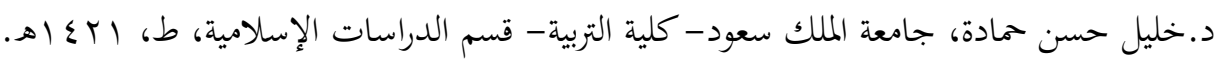

0. المعجم الأوسط: للإمام أبي القاسم سليمان بن أحمد بن أيوب الطبراني (ت. بـه)، تحقيق: طارق ابن عوض الله بن مُحَّة، وعبد المحسن الحسني، دار الحرمين، القاهرة.

4ه. المعجم الكبير: للإمام أبي القاسم سليمان بن أحمد بن أيوب الطبراني (ت . ب هـ)، تحقيق: حمدي بن عبد المجيد ، مكتبة القاهرة، طب، ع 99 ام. 
Published by the College of Islamic Sciences at the University of Fallujah ISSN p.p:2708-3993 / ISSN o.I: 2708-4000

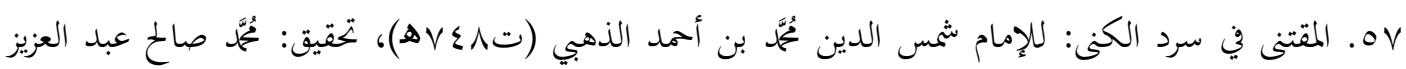
المراد، مطابع الجامعة الإسلامية- المدينة المنورة، 1 •ـ الهـ

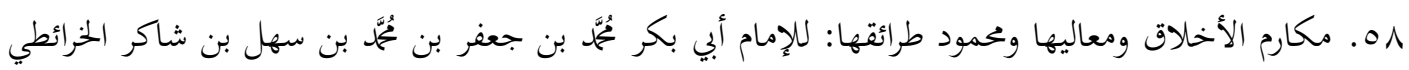

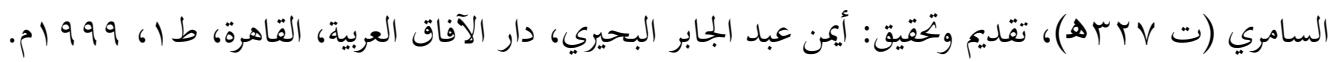
9ه. موجبات الجنة: للإمام ابي احمد معمر بن عبد الواحد بن رجاء بن عبد الواحد بن ثُمَّمَ بن الفاخر، القرشي العبشمي السمرقندي الأصبهاني (ت عـهـه)، المقق: ناصر بن أحمد بن النجار الدمياطي، مكتبة عباد

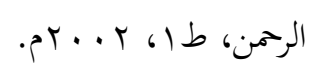

• جا. موسوعة أقوال أبي الحسن الدارقطني في رجال الحديث وعلله: مجموعة من المؤلفين، عالم الكتب للنشر

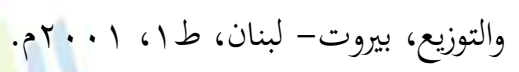

ال7. موسوعة أقوال الإمام أحمد بن حنبل في رجال الحديث وعلله: جمع وترتيب: السيد أبو المعاطي النوري - أحمد

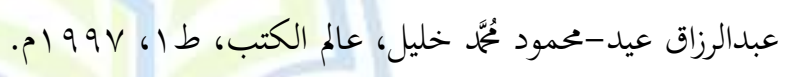

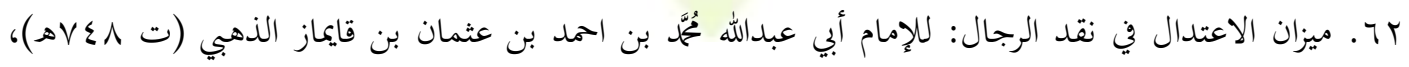

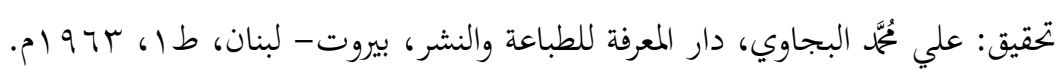

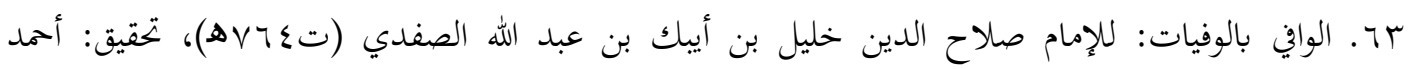

$$
\text { الأرناؤوط وتركي مصطفى، دار إحياء التراث- بيروت، . ... بام. }
$$

